\title{
Short-Term Monitoring Results for Advanced New Construction Test House- Roseville, California
}

D. Stecher, K. Brozyna, and C. Imm IBACOS, Inc. 


\section{NOTICE}

This report was prepared as an account of work sponsored by an agency of the United States government. Neither the United States government nor any agency thereof, nor any of their employees, subcontractors, or affiliated partners makes any warranty, express or implied, or assumes any legal liability or responsibility for the accuracy, completeness, or usefulness of any information, apparatus, product, or process disclosed, or represents that its use would not infringe privately owned rights. Reference herein to any specific commercial product, process, or service by trade name, trademark, manufacturer, or otherwise does not necessarily constitute or imply its endorsement, recommendation, or favoring by the United States government or any agency thereof. The views and opinions of authors expressed herein do not necessarily state or reflect those of the United States government or any agency thereof.

Available electronically at http://www.osti.gov/bridge

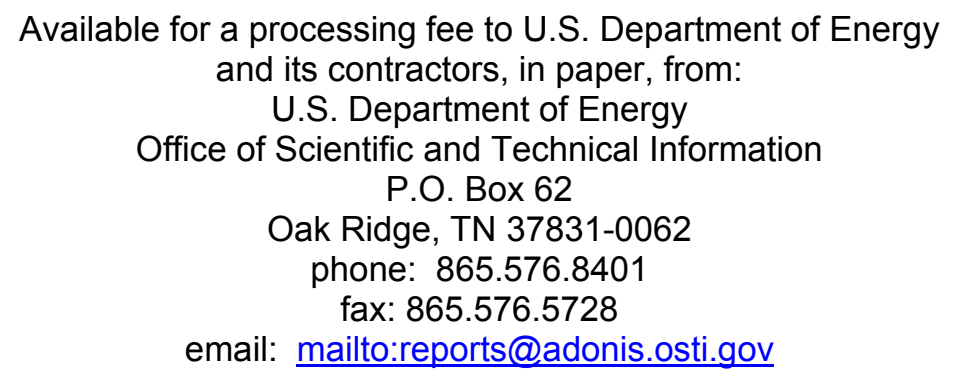

Available for sale to the public, in paper, from:

U.S. Department of Commerce

National Technical Information Service

5285 Port Royal Road

Springfield, VA 22161

phone: 800.553 .6847

fax: 703.605 .6900

email: orders@ntis.fedworld.gov

online ordering: http://www.ntis.gov/ordering.htm 


\title{
Short-Term Monitoring Results for Advanced New Construction Test House-Roseville, California
}

\author{
Prepared for: \\ The National Renewable Energy Laboratory \\ On behalf of the U.S. Department of Energy's Building America Program \\ Office of Energy Efficiency and Renewable Energy \\ 15013 Denver West Parkway \\ Golden, CO 80401 \\ NREL Contract No. DE-AC36-08GO28308
}

\author{
Prepared by: \\ D. Stecher, K. Brozyna, and C. Imm \\ IBACOS, Inc. \\ 2214 Liberty Avenue \\ Pittsburgh, PA 15222 \\ NREL Technical Monitor: Michael Gestwick \\ Prepared under Subcontract No. KNDJ-0-40341-02
}

September 2013 
\begin{tabular}{l|l} 
u.s. DEPARTMEnt of & Energy Efficiency \& \\
ENERCY & Renewable Energy
\end{tabular}

[This page left blank] 


\section{Table of Contents}

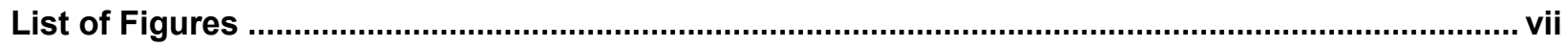

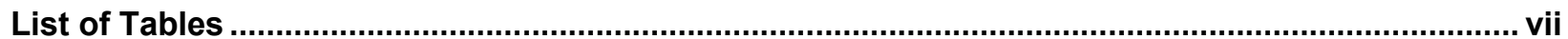

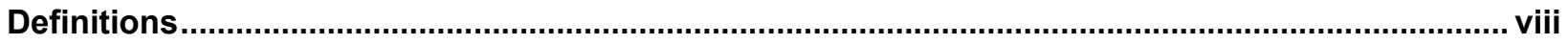

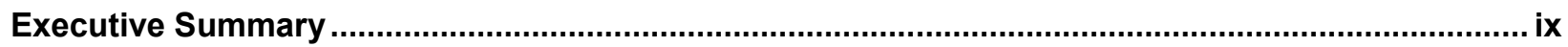

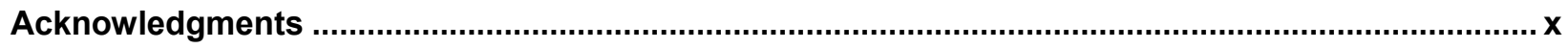

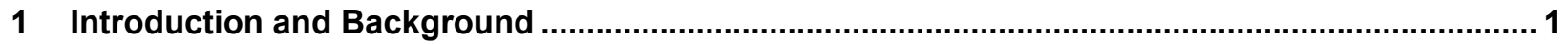

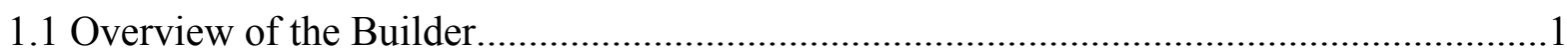

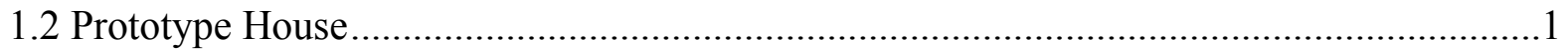

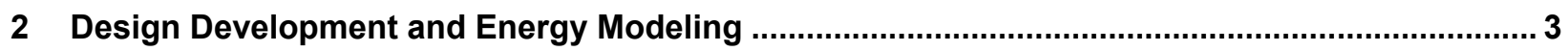

2.1 Systems Integrated Measures Package Development................................................... 3

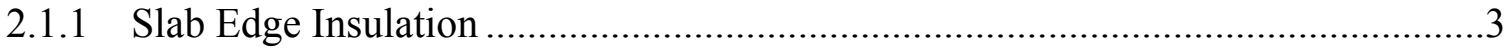

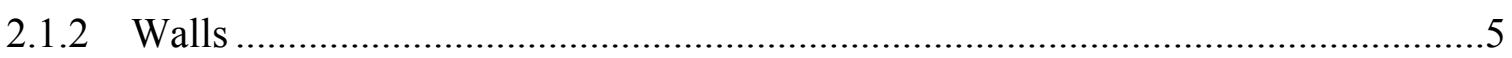

2.1.3 Systems Integrated Measures Package Comparison ............................................6

2.1.4 Strategy for Locating Ductwork in Conditioned Space ......................................

2.2 Whole-House Energy Modeling ......................................................................... 14

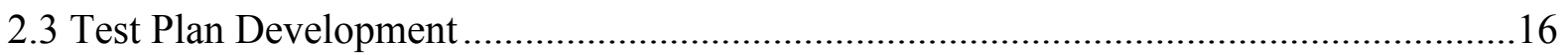

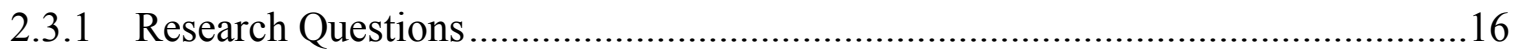

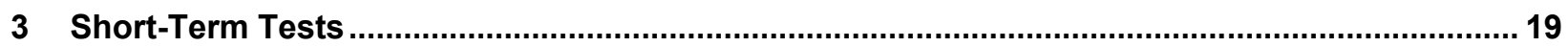

3.1 Room-by-Room Supply Register Airflow ....................................................................19

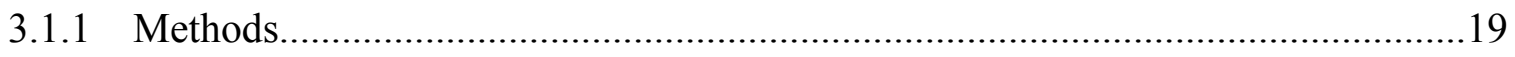

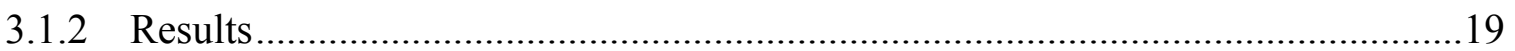

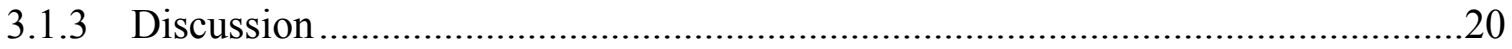

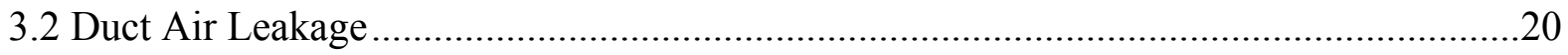

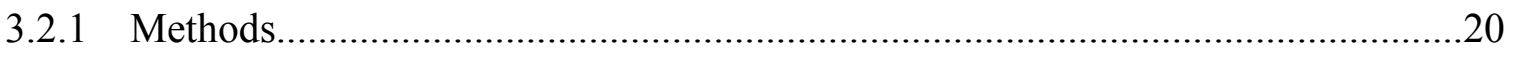

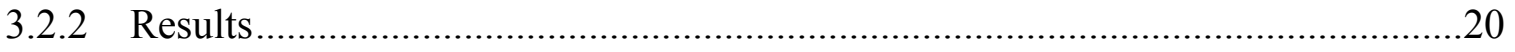

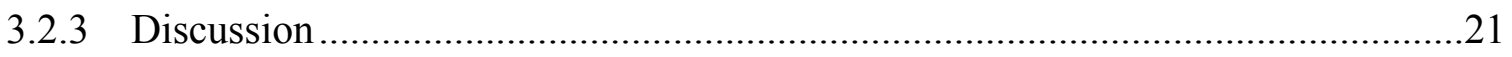

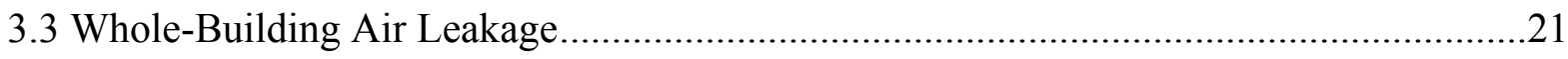

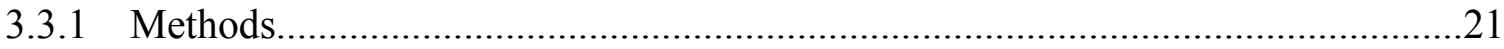

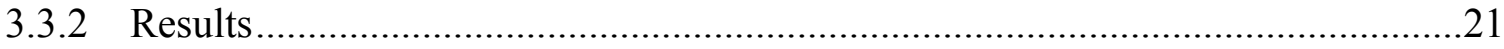

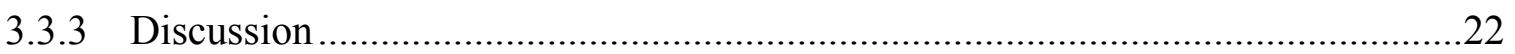

3.4 Recessed Light Fixture and Wall Penetration Air Leakage .........................................22

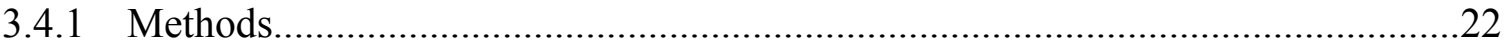

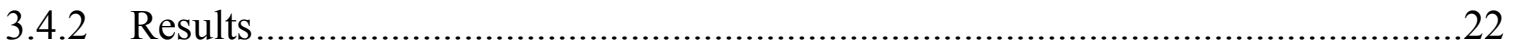

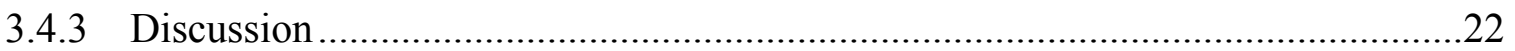

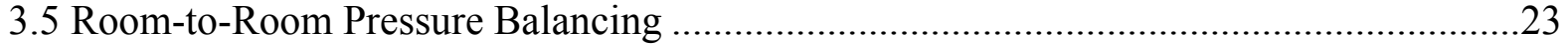

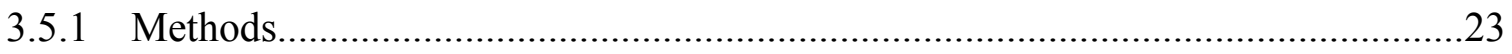

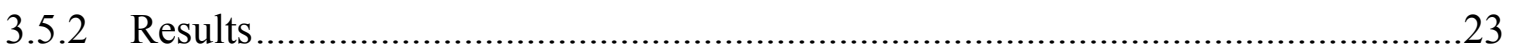

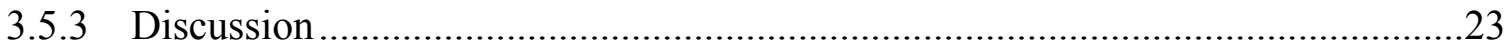




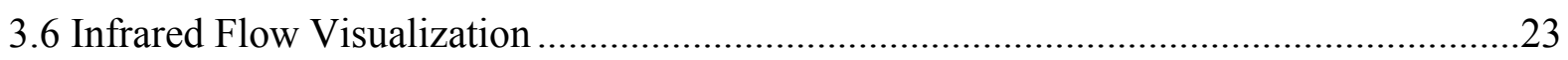

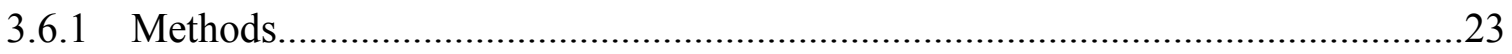

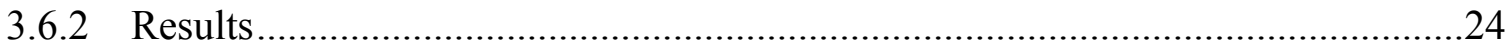

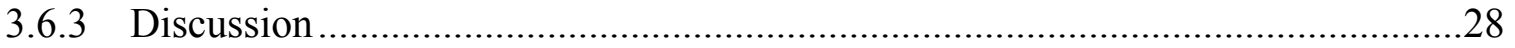

3.7 In-Room Temperature Uniformity Measurements .................................................28

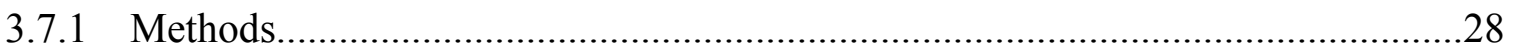

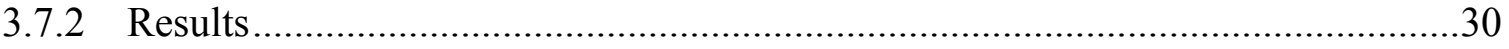

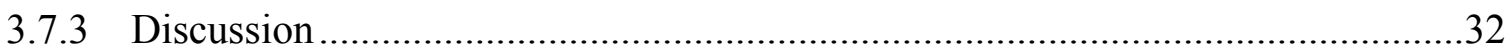

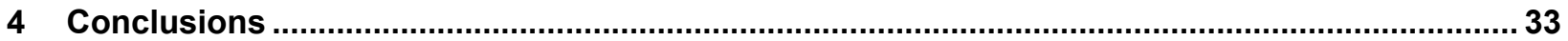

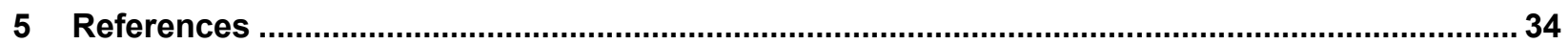




\section{List of Figures}

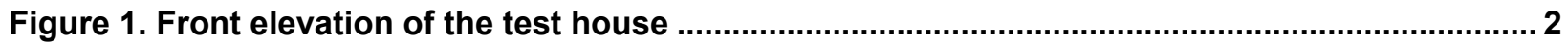

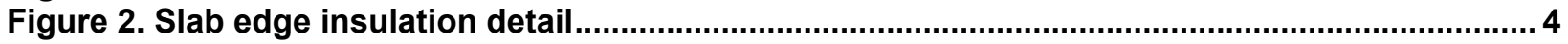

Figure 3. Mechanical equipment and ductwork within unconditioned space of the vented attic .... 10

Figure 4. Mechanical equipment and ductwork within the semiconditioned bulkhead space

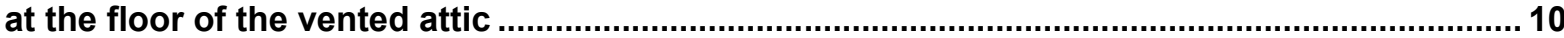

Figure 5. Standard roof truss for the builder's Plan 4 houses ..................................................... 11

Figure 6. Modified roof truss for the Plan 4 test house, which provides a chase for ductwork at the ceiling plane and has 16 -in. raised heels along the perimeter...

Figure 7. Final layout of the centrally located bulkhead and mechanical equipment inside a closet

Figure 8. Ductwork centrally distributed within the conditioned space of the bulkhead at the attic floor

Figure 9. Output from BEopt source energy modeling by subcategory ........................................... 16

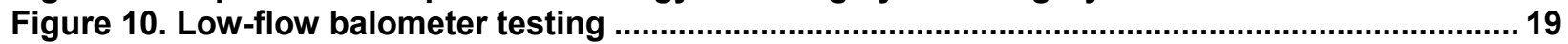

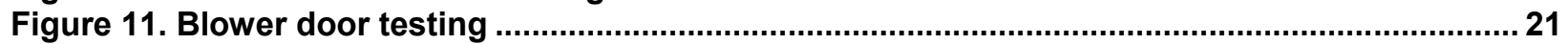

Figure 12. Black felt IR viewing screen positioned adjacent to an exterior wall and parallel to the primary register airflow path.............................................................................................. 24

Figure 13. IR photo of black felt screen during cooling system operation (temperature scale in ${ }^{\circ} \mathrm{F}$ ).

Figure 14. IR photo of black felt screen during heating system operation (temperature scale

in $\left.{ }^{\circ} \mathrm{F}\right)$...................................................................................................... stratification (temperature scale in ${ }^{\circ} \mathrm{F}$ ).

Figure 16. IR photo showing vertical stratification (temperature scale in ${ }^{\circ} \mathrm{F}$ )

Figure 17. IR photo showing uniform horizontal distribution of heated air (temperature scale in ${ }^{\circ} \mathrm{F}$ ).

Figure 18. Layout of temperature measurements ....

Figure 19. Sensor stands and a supply register in the kitchen/family room area........................... 30

Figure 20. Temperatures $\left({ }^{\circ} \mathrm{C}\right)$ at various sensor locations in the kitchen/family room area during $1 \mathrm{~h}$

Figure 21. Temperatures $\left({ }^{\circ} \mathrm{C}\right)$ at various sensor locations in the master bedroom during $1 \mathrm{~h} . . . . . . .32$

Unless otherwise noted, all figures and photos were created by IBACOS.

\section{List of Tables}

Table 1. SIMPs for K. Hovnanian Homes. .................................................................................. 7

Table 2. Sample of Modeling Results from Mechanical Equipment and Ductwork Location

Evaluation.

Table 3. Comparison of Standard Versus Prototype House Specifications.

Tests.

Table 4. Research Measurements and Equipment for Short-Term Characterization Tests.............. 18

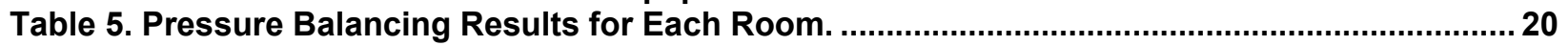

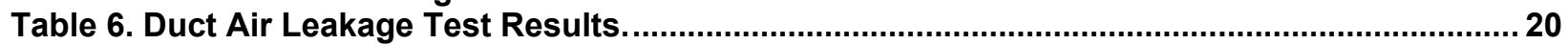

Table 7. Characterization Testing: House Leakage.......................................................................... 22

Unless otherwise noted, all tables were created by IBACOS. 


\section{Definitions}

ACCA

$\mathrm{ACH}$

AFUE

AHU

BA

BEopt

CEC

cfm

$\mathrm{EF}$

FF

HERS

HVAC

ICC

IR

$\mathrm{kW}$

$\mathrm{kWh}$

$\mathrm{Pa}$

PV

SEER

SHGC

SIMP

XPS
Air Conditioning Contractors of America

Air changes per hour

Annual fuel utilization efficiency

Air-handling unit

Building America

Building Energy Optimization

California Energy Commission

Cubic foot per minute

Energy factor

Finished floor

Home Energy Rating System

Heating, ventilation, and air conditioning

International Code Council

Infrared

Kilowatt

Kilowatt-hour

Pascal

Photovoltaic

Seasonal energy efficiency ratio

Solar heat gain coefficient

Systems integrated measures package

Extruded polystyrene 


\section{Executive Summary}

A test house constructed in Roseville, California, has a modeled energy savings of $60 \%$ with respect to the Building America House Simulation Protocols (Hendron and Engebrecht 2010). This prototype is a $2,253-\mathrm{ft}^{2}$ single-story slab-on-grade ranch house with three bedrooms and two full bathrooms.

To accomplish this increase in energy efficiency while minimizing construction costs, the builder (K. Hovnanian Homes), design consultant, and trades collaborated to identify a systems integrated measures package. This design development process for the test house lasted from late November 2010 through early July 2011.

One of the key building improvements that the team chose to incorporate was applying R-10 insulation to the slab edge. This strategy consisted of insulating the slab edge on the exterior from $1 \mathrm{in}$. below the finished floor to a depth of $15 \mathrm{in}$. below the finished floor with 2-in.-thick extruded polystyrene (R-10 total).

Several alternatives were considered to improve the thermal performance of the walls, but the decision was made to increase the standard-density R-13 fiberglass batt in the wall cavity with a higher density R-15 fiberglass batt. The attic insulation also was increased from R-30 to R-38.

Regarding placement of the mechanical heating, ventilation, and air-conditioning equipment, the air-handling unit was relocated from the unconditioned attic to a central location inside the conditioned space of the house. Likewise, the ductwork was relocated within the thermal enclosure along the attic floor by building an insulated bulkhead above it. All energy improvements were implemented without requiring changes to the drawings that would impact local code or zoning approval.

IBACOS used a combination of REM/Rate ${ }^{\mathrm{TM}}$ and EnergyGauge USA modeling to evaluate the whole-house energy consumption of the prototype. Energy modeling using Building Energy Optimization Version 1.3 was also performed. Although models predicted that the builder's standard inputs would provide a savings of $11.8 \%$ relative the Building America House Simulation Protocols (Hendron and Engebrecht 2010), the prototype house specifications provided savings of $35 \%$ without photovoltaics and $60 \%$ with photovoltaics (both relative to the Building America House Simulation Protocols; see Hendron and Engebrecht 2010).

Research questions focused on measuring the performance of the proposed space conditioning system and the capacity of the system to maintain acceptable levels of indoor temperature and relative humidity. Short-term testing and commissioning of long-term monitoring equipment were performed.

The airflow from each supply register in each room was measured using a calibrated low-flow balometer, and the tightness of the air distribution system was tested with a duct blaster to determine the total air leakage in the system and, in conjunction with the blower door test, to determine air leakage to the outdoors. During the blower door test, further testing was conducted to measure air leakage around recessed light fixtures and wall penetration air leakage. 
A digital manometer was also used to measure the pressure difference between rooms with the doors closed to the central space while the mechanical system was operating to ensure the installed over-the-door transfer grilles operated as an adequate passive return pathway.

Flow visualization testing using an infrared thermal imaging camera was conducted in the master bedroom to determine the temperature uniformity of those spaces provided by the compact duct system layout and the use of ceiling-mounted supply distribution. Further in-room temperature uniformity measurements were also conducted at five critical locations throughout the master bedroom and six locations throughout the kitchen/family room area.

The results of the short-term testing showed that duct air leakage was low, as anticipated, due to the short duct runs and the placement of the ductwork in conditioned space. Whole-building air leakage improved considerably after air sealing all penetrations through the drywall. However, recessed light fixture and wall penetration leakage showed significant air leakage levels, and exhaust fans represented another source of air leakage.

One problem foreseen during planning was realized during commissioning, where the lack of access for servicing the ductwork and dampers in the bulkhead area prevented retroactive balancing of individual branches, resulting in significant differences between specified and measured airflow values for some duct runs. The results of thermal imaging performed for the house when operating in both the heating mode and the cooling mode showed that the alternative register placement in the test house provided equivalent horizontal distribution to the builder's standard house. The tests validated historical stratification issues of ceiling supply registers with high supply air temperatures.

Long-term monitoring results for this test house will be detailed in a future report after at least 1 year of monitored data has been collected.

\section{Acknowledgments}

This report was prepared for the U.S. Department of Energy Building America program. Funding for this work was provided by the National Renewable Energy Laboratory under Subcontract No. KNDJ-0-40341-02.

The authors wish to thank Ed Hancock and Lieko Earle for their assistance in short-term testing and monitoring equipment commissioning. 


\section{Introduction and Background}

\subsection{Overview of the Builder}

K. Hovnanian Homes is headquartered in Red Bank, New Jersey. Founded more than 50 years ago, K. Hovnanian Homes has grown into a company with divisions building homes in 199 communities across 16 states. In 2011, the company had 4,316 closings and was ranked the nation's seventh largest builder of new homes in the United States by Professional Builder magazine.

\subsection{Prototype House}

The prototype house is located in the Stone Mill community of the Fiddyment Farm master plan in the northwest portion of the City of Roseville, within Placer County, California. The development of this community is considered part of K. Hovnanian Homes' Sacramento region, which is overseen by its Northern California group. The community is composed of 135 home sites and offers several one- and two-story slab-on-grade plan types ranging in size from approximately 2,500 to $3,750 \mathrm{ft}^{2}$. With prices starting in the mid- to upper $\$ 300,000$ range, these homes are priced closer to the upper end of the market and are targeting second-time and moveup home buyers.

The Northern California group of K. Hovnanian Homes decided to participate in the Building America (BA) program with IBACOS to design and construct a test house with several goals in mind:

- Evaluate the benefits, costs, and challenges of the technologies and building practices that are available on the market and that can be readily incorporated into current production.

- Experiment with those technologies that will enable compliance with upcoming building code cycles in order to be prepared when higher performing codes are required in the future.

- Provide the builder's trade contractors the opportunity to recommend and construct alternative practices for bringing mechanical equipment and ductwork inside the conditioned space and improving the overall thermal performance and airtightness of the building enclosure.

- Demonstrate to the regional team and trade contractors the benefits of using a wholehouse systems integrated approach to designing and constructing a home.

The builder elected to construct a ranch-style house in Roseville, California, that would achieve the $60 \%$ level of source energy savings in relation to the BA House Simulation Protocols (Hendron and Engebrecht 2010). A popular house type that K. Hovnanian Homes develops in the region, Plan 4 is a 2,253- $\mathrm{ft}^{2}$ single-story slab-on-grade home that has three bedrooms and two full bathrooms. Figure 1 shows the front elevation of the test house. 


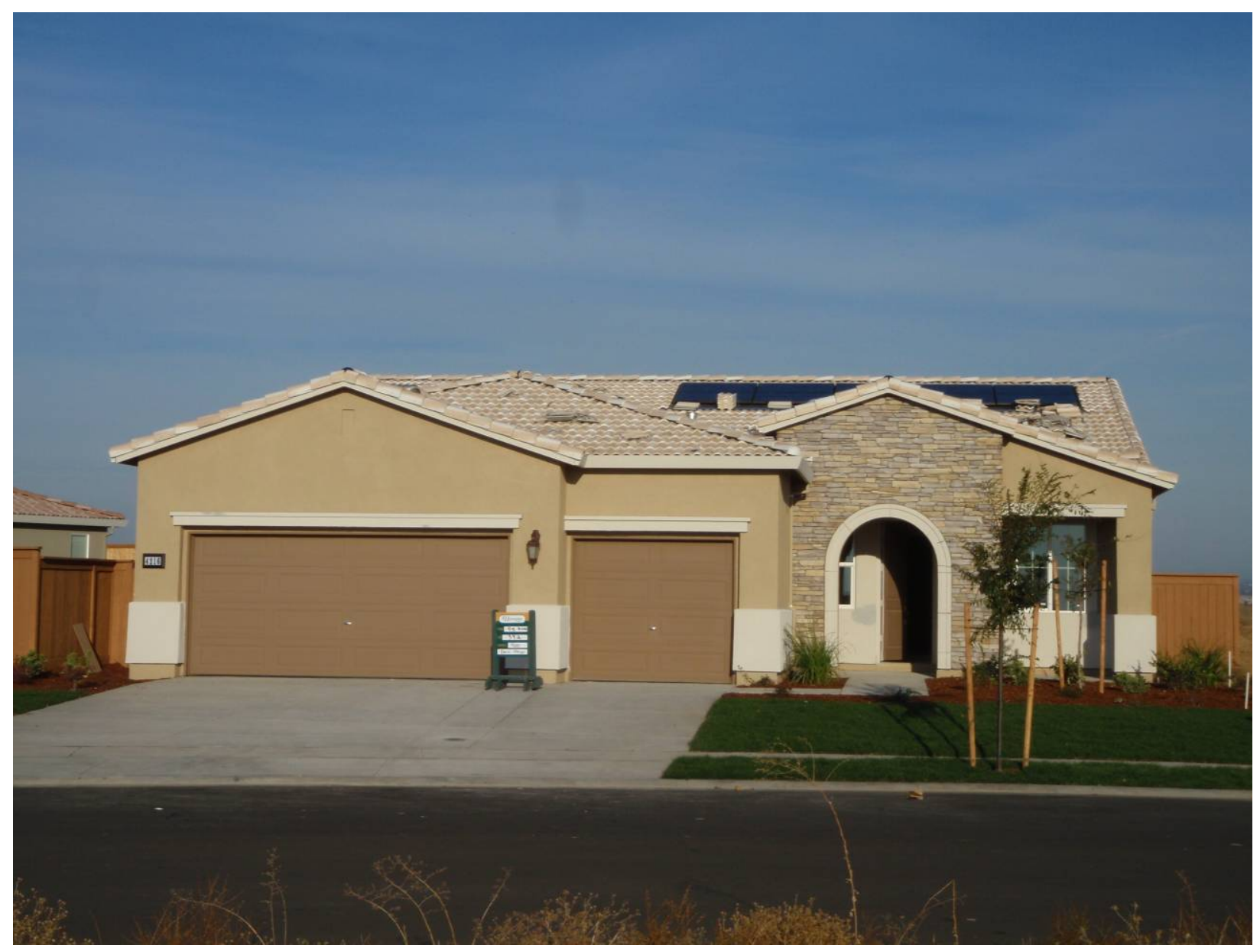

Figure 1. Front elevation of the test house

The current standards for the builder's Northern California group are is ENERGY STAR ${ }^{\circledR} 2.0$ and Title 24 of the California Building Code (California Building Standards Commission 2007). Selection of the systems integrated measures package (SIMP) for the test house to achieve the $60 \%$ level of energy savings required several months of iterative design and costing analysis in early 2011. During this process, modeling was performed using a combination of Building Energy Optimization (BEopt) Version 1.3, EnergyGauge USA Version 2.8.03, and REM/Rate Version 12.96 to demonstrate the impact on whole-house energy use among various building SIMPs while using the California Energy Commission (CEC) 2008 Building Energy Efficiency Standards requirements as a baseline for comparing the various packages (CEC 2010).

BEopt Version 1.3 was used to evaluate the current level of building performance of the entire division, with the builder's standard specification package achieving an $11.8 \%$ level of source energy savings with respect to the BA House Simulation Protocols (Hendron and Engebrecht 2010) using a combination of REM/Rate Version 12.96, EnergyGauge USA Version 2.8.03, and BEopt Version 1.3 modeling tools. 


\section{Design Development and Energy Modeling}

\subsection{Systems Integrated Measures Package Development}

The design development process for the test house began in late November 2010 and ended in early July 2011. During this time, IBACOS worked with the builder to perform several rounds of modeling to evaluate the impact on whole-house energy performance and cost for various building enclosure components that included exterior walls, insulated ceiling assembly, slab edge insulation, windows, and building envelope airtightness. Ultimately, the goal of the enclosure evaluation was to identify a cost-effective insulation strategy for the building envelope that would help reduce the heating and cooling load requirements of the home and would allow for the mechanical equipment and ductwork to be centrally located within conditioned space. Locating the mechanical equipment and ductwork inside conditioned space was a key feature in the design of the home because the builder recognized that regional building codes are moving toward making this building practice mandatory.

The builder's team is very conscious of the impact that building systems improvements may have on the construction cost of its homes if trade-offs are not evaluated as part of a whole-house systems approach to design. Consideration of existing, as well as upcoming, code requirements was a critical part of the evaluation process for the builder. Identifying the building practices that would allow the builder to satisfy the requirements of the 2008 Building Energy Efficiency Standards (CEC 2010) and prepare for the proposed 2013 code and ENERGY STAR Version 3.0 requirements were the basic guidelines for the packages of measures outlined. The key building improvements that the builder wanted to incorporate were changes to the slab edge, exterior walls, and attic insulation. These improvements would allow the company to reduce the size of the mechanical equipment and consider bringing it inside the conditioned space at a central location in the house.

\subsubsection{Slab Edge Insulation}

As a result of the increased focus of upcoming codes on reducing energy loss through the floor slab (International Energy Conservation Code 2009; 2012), IBACOS worked with the builder to evaluate the impact and benefit of introducing insulation at the foundation level. Several approaches were analyzed, including horizontal insulation under the entire slab, horizontal insulation around the inside perimeter of the slab, and vertical insulations along the interior and exterior portions of the footings.

After discussions with the builder, it was determined that the strategy with the best energy performance - insulating the slab edge and underside of the footing - would not be practical to construct in a reasonable time frame due to perceived difficulties in receiving approval from local code officials for the use of foam under a load-bearing portion of the foundation. The builder's team agreed to the slab edge insulation strategy shown in Figure 2. ${ }^{1}$ The strategy consists of insulating the slab edge on the exterior from $1 \mathrm{in}$. below the finished floor (FF) to a depth of 15 in. below the FF with 2-in.-thick extruded polystyrene (XPS; R-10 total). Although

\footnotetext{
${ }^{1}$ The open stud framing method shown in Figure 2 is prevalent in the southwestern United States (e.g., Southern California, Nevada, Arizona, and New Mexico). For the most part, the building paper is unsupported (i.e., there is "let-in" bracing and/or shear panels but no wood sheathing over most of the wall plane).
} 
the XPS does not cover the entire height of the slab edge, it is the solution that provided the best insulation for its installation efforts.

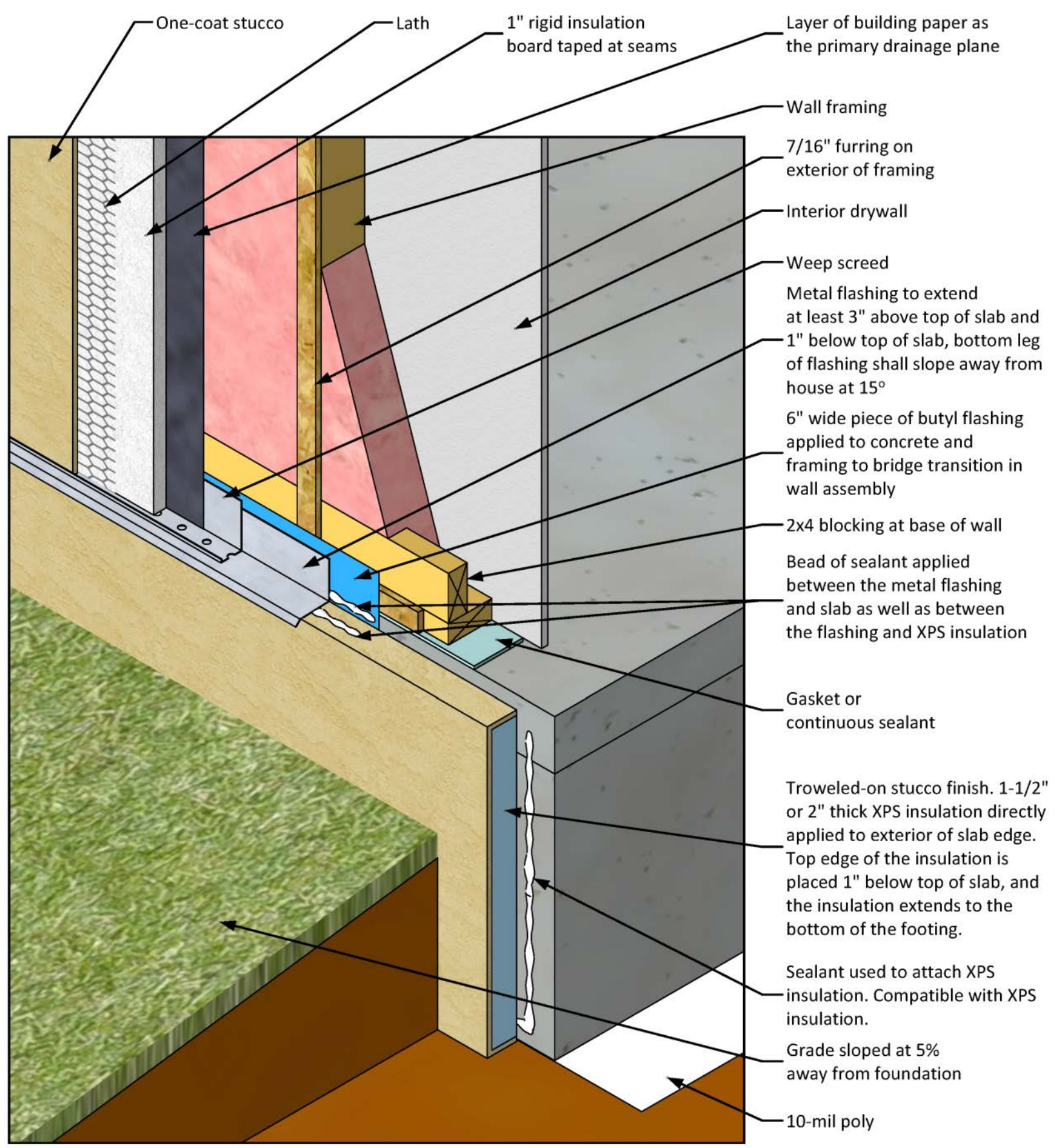

Figure 2. Slab edge insulation detail

To implement this strategy, the foundation contractor was asked to install an additional 8-in.high form board to the bottom of the existing one to ensure that there was a minimum of 18 in. of smooth slab edge down from the FF. After the form work was removed, the foundation contractor applied the foam to the edge of the slab. To allow for the detailing of the termite break 
and flashing details, the top of the foam was located $1 \mathrm{in.} \mathrm{below} \mathrm{the} \mathrm{FF} \mathrm{height.} \mathrm{It} \mathrm{extended} \mathrm{to}$ $15 \mathrm{in.} \mathrm{below} \mathrm{the} \mathrm{FF} \mathrm{height} \mathrm{for} \mathrm{a} \mathrm{total} \mathrm{of} 14 \mathrm{in.} \mathrm{of} \mathrm{foam} \mathrm{board.} \mathrm{The} \mathrm{foam} \mathrm{was} \mathrm{held} \mathrm{in} \mathrm{place} \mathrm{by}$ construction adhesive and backfill at the slab edge.

Several finishes for the foam were evaluated, including painted galvanized sheet metal, selfadhering flexible polyvinyl chloride sheet material, and troweled-on stucco. Concerns with longterm maintenance and ease of repair led the team to select troweled-on stucco as the finish. This also allowed for the best color and finish match between the slab edge and the above-grade wall.

\subsubsection{Walls}

For the exterior walls, IBACOS and the builder discussed several opportunities to increase the thermal performance of the walls. The builder's standard wall assembly consisted of $2 \times 4$ wood framing, with R-13 batts in the cavity and a one-coat stucco system (including R-3 expanded polystyrene insulating sheathing) on the exterior. The following possible improvements were discussed with the builder and its trade contractors:

- Changing the framing from 16-in. on-center (o.c.) $2 \times 4$ boards to 24 -in. o.c. $2 \times 6$ boards

- Using a higher R-value/inch rigid insulation board on the exterior in conjunction with the one-coat stucco system

- Using higher R-value/inch cavity fill insulation.

It was determined that making the shift to a $2 \times 6$ advanced framed wall required unacceptable changes, including reducing the interior square footage of the home (which would require the plan set to be redrawn and reapproved by the township) and changing the window and door frame details.

Discussed next were the options of changing the R-3/inch expanded polystyrene board used with the one-coat stucco system to either R-5/in. XPS board or R-6.5/in. polyisocyanurate board. When reviewed with the stucco contractor, it was determined that neither of these alternative boards had been approved for use with the stucco system, which was a fire-rated assembly. Therefore, without additional testing and certifications being pursued, neither of these options could be used.

The remaining improvement considered was swapping the standard-density R-13 fiberglass batt in the wall cavity with a higher-density R-15 fiberglass batt. The builder realized that the impact on the design and installation process of the cavity insulation would be negligible and agreed to incorporate this change.

Because the monolithic stucco finish contributed to exterior walls that were inherently airtight, attention turned to air sealing the attic. This was accomplished by applying spray foam insulation to the penetrations into the attic and at junctions between the top plates of interior partition walls and ceiling drywall. In addition to these improved enclosure measures, which led to reduced air infiltration through the building envelope, IBACOS recommended that the builder should consider ventilation strategies to ensure that outside makeup air would be introduced into its homes as well. 


\subsubsection{Systems Integrated Measures Package Comparison}

As a result of these discussions, IBACOS developed the packages of measures listed in Table 1 to fulfill the requirements outlined by the builder. The table shows the system improvements made among the various packages, as well as the estimated source energy use and Home Energy Rating System (HERS) Index for each package of measures.

During the SIMP evaluation process, the builder's marketing team requested that IBACOS develop a comprehensive analysis of how houses available in the region compare to the builder's standard product, as well as the high performance packages that were being considered for the test house. Incorporating this added level of evaluation into the analysis would enable the builder's sales team to demonstrate to potential customers the anticipated savings they could experience when purchasing a new home from the builder versus an older home on the market. Therefore, based on input from the builder about the typical age of homes available on the market, IBACOS developed two SIMPs that represented homes constructed to the 1990s and early 2000s code levels of performance. Table 1 includes both SIMPs.

A note about modeling should be added here. Initially, IBACOS utilized BEopt and EnergyGauge USA to conduct the whole-house energy modeling. Feedback from the builder was that the modeling results were not useful for its evaluation because those modeling results did not relate to a performance metric with which the builder or its building raters were familiar. Therefore, IBACOS chose to use REM/Rate software because the builder's energy rating consultants use it and because the output from that program would provide a HERS Index, a widely accepted industry metric with which the consultants would be familiar. 
Table 1. SIMPs for K. Hovnanian Homes

\begin{tabular}{|c|c|c|c|c|c|c|c|c|}
\hline & \multicolumn{8}{|c|}{ SIMPs } \\
\hline $\begin{array}{l}\text { Building } \\
\text { System }\end{array}$ & $\begin{array}{l}\text { 1990s } \\
\text { House }\end{array}$ & $\begin{array}{l}\text { 2000s } \\
\text { House }\end{array}$ & $\begin{array}{l}\text { Standard } \\
\text { House }\end{array}$ & $\begin{array}{l}\text { Standard } \\
\text { House with } \\
\text { Slab Edge } \\
\text { Insulation }\end{array}$ & Option 1 & $\begin{array}{c}\text { Option } 1 \\
\text { with } \\
\text { Slab Edge } \\
\text { Insulation }\end{array}$ & Option 2 & $\begin{array}{l}\text { Option } 2 \\
\text { with } \\
\text { Solar } \\
\text { PV }\end{array}$ \\
\hline Enclosure & $\begin{array}{c}2 \times 4 \text { wood } \\
\text { framed, R-11 } \\
\text { batt cavity } \\
\text { insulation, } \\
\text { R-30 blown } \\
\text { insulation at } \\
\text { attic floor, } \\
\text { windows } \\
\mathrm{U}=0.65 \text { and } \\
\mathrm{SHGC}=0.70, \\
\mathrm{ACH}_{50}=8\end{array}$ & $\begin{array}{c}2 \times 4 \text { wood } \\
\text { framed, R-13 } \\
\text { batt cavity } \\
\text { insulation, } \\
\text { R-30 blown } \\
\text { insulation at } \\
\text { attic floor, } \\
\text { windows } \\
\mathrm{U}=0.60 \text { and } \\
\mathrm{SHGC}=0.40, \\
\mathrm{ACH}_{50}=6\end{array}$ & $\begin{array}{c}2 \times 4 \text { wood } \\
\text { framed, R-3 } \\
\text { one-coat stucco, } \\
\text { R-13 batt cavity } \\
\text { insulation, R-30 } \\
\text { blown insulation } \\
\text { at attic floor, } \\
\text { windows } \\
\mathrm{U}=0.35 \text { and } \\
\mathrm{SHGC}=0.30, \\
\mathrm{ACH}_{50}=3\end{array}$ & $\begin{array}{c}2 \times 4 \text { wood } \\
\text { framed, R-3 } \\
\text { one-coat stucco, } \\
\text { R-13 batt cavity } \\
\text { insulation, R-30 } \\
\text { blown insulation } \\
\text { at attic floor, } \\
\text { windows } \\
\mathrm{U}=0.35 \text { and } \\
\mathrm{SHGC}=0.30, \\
\mathrm{ACH} \\
\text { R0 } \\
\mathrm{R}-10 \text { slab edge } \\
\text { insulation } \\
\text { vertical around } \\
\text { the exterior } \\
\text { perimeter }\end{array}$ & $\begin{array}{c}2 \times 4 \text { wood } \\
\text { framed, R-3 } \\
\text { one-coat stucco, } \\
\text { R-13 batt cavity } \\
\text { insulation, R-38 } \\
\text { blown insulation } \\
\text { at attic floor, } \\
\text { windows } \\
\mathrm{U}=0.35 \text { and } \\
\mathrm{SHGC}=0.30, \\
\mathrm{ACH} \\
50\end{array}$ & $\begin{array}{c}2 \times 4 \text { wood } \\
\text { framed, R-3 } \\
\text { one-coat stucco, } \\
\text { R-13 batt cavity } \\
\text { insulation, R-38 } \\
\text { blown insulation } \\
\text { at attic floor, } \\
\text { windows } \\
\mathrm{U}=0.35 \text { and } \\
\mathrm{SHGC}=0.30, \\
\mathrm{ACH} \\
\text { R- }=3 \text {, } \\
\text { Rlab } \\
\text { insulation } \\
\text { vertical around } \\
\text { the exterior } \\
\text { perimeter }\end{array}$ & $\begin{array}{c}2 \times 4 \text { wood } \\
\text { framed, R-3 one- } \\
\text { coat stucco, R-15 } \\
\text { batt cavity } \\
\text { insulation, R-38 } \\
\text { blown insulation } \\
\text { at attic floor, } \\
\text { radiant barrier at } \\
\text { roof deck, } \\
\text { windows } \\
\mathrm{U}=0.28 \text { and } \\
\mathrm{SHGC}=0.26, \\
\text { ACH }{ }_{50}=1.7 \text {, } \\
\mathrm{R}-10 \text { slab } \\
\text { insulation vertical } \\
\text { around the } \\
\text { exterior perimeter }\end{array}$ & $\begin{array}{c}2 \times 4 \text { wood } \\
\text { framed, R-3 one- } \\
\text { coat stucco, R-15 } \\
\text { batt cavity } \\
\text { insulation, R-38 } \\
\text { blown insulation } \\
\text { at attic floor, } \\
\text { radiant barrier at } \\
\text { roof deck, } \\
\text { windows } \\
\mathrm{U}=0.28 \text { and } \\
\mathrm{SHGC}=0.26, \\
\text { ACH } \\
\text { Ro }=1.7 \text { slab } \\
\text { insulation vertical } \\
\text { around the } \\
\text { exterior perimeter }\end{array}$ \\
\hline Heating & $\begin{array}{c}78 \% \text { AFUE gas } \\
\text { furnace, no } \\
\text { ventilation }\end{array}$ & $\begin{array}{c}80 \% \text { AFUE gas } \\
\text { furnace, no } \\
\text { ventilation }\end{array}$ & $\begin{array}{l}80 \% \text { AFUE gas } \\
\text { furnace, exhaust } \\
\text { only ventilation }\end{array}$ & $\begin{array}{l}80 \% \text { AFUE gas } \\
\text { furnace, exhaust } \\
\text { only ventilation }\end{array}$ & $\begin{array}{l}95 \% \text { AFUE gas } \\
\text { furnace, exhaust } \\
\text { only ventilation }\end{array}$ & $\begin{array}{l}95 \% \text { AFUE gas } \\
\text { furnace, exhaust } \\
\text { only ventilation }\end{array}$ & $\begin{array}{c}95 \% \text { AFUE gas } \\
\text { furnace, balanced } \\
\text { ventilation, ducts } \\
\text { inside conditioned } \\
\text { space }\end{array}$ & $\begin{array}{c}\text { 95\% AFUE gas } \\
\text { furnace, balanced } \\
\text { ventilation, ducts } \\
\text { inside conditioned } \\
\text { space }\end{array}$ \\
\hline $\begin{array}{l}\text { Cooling (air- } \\
\text { conditioning } \\
\text { unit) }\end{array}$ & 10 SEER & 10 SEER & 13 SEER & 13 SEER & 14.5 SEER & 14.5 SEER & 16 SEER & 16 SEER \\
\hline Hot Water & $\begin{array}{c}50 \text {-gal gas, } \\
\mathrm{EF}=0.53\end{array}$ & $\begin{array}{c}50 \text {-gal gas, } \\
\mathrm{EF}=0.58\end{array}$ & $\begin{array}{c}50 \text {-gal gas, } \\
\mathrm{EF}=0.60\end{array}$ & $\begin{array}{c}50 \text {-gal gas, } \\
\mathrm{EF}=0.60\end{array}$ & $\begin{array}{c}50 \text {-gal gas, } \\
\mathrm{EF}=0.62\end{array}$ & $\begin{array}{c}50 \text {-gal gas, } \\
\mathrm{EF}=0.62\end{array}$ & $\begin{array}{c}\text { Tankless gas, } \\
\mathrm{EF}=0.94\end{array}$ & $\begin{array}{c}\text { Tankless gas, } \\
\mathrm{EF}=0.94\end{array}$ \\
\hline
\end{tabular}




\begin{tabular}{|c|c|c|c|c|c|c|c|c|}
\hline & \multicolumn{8}{|c|}{ SIMPs } \\
\hline $\begin{array}{l}\text { Building } \\
\text { System }\end{array}$ & $\begin{array}{l}1990 \text { s } \\
\text { House }\end{array}$ & $\begin{array}{l}\text { 2000s } \\
\text { House }\end{array}$ & $\begin{array}{l}\text { Standard } \\
\text { House }\end{array}$ & $\begin{array}{c}\text { Standard } \\
\text { House with } \\
\text { Slab Edge } \\
\text { Insulation } \\
\end{array}$ & Option 1 & $\begin{array}{l}\text { Option } 1 \\
\text { with } \\
\text { Slab Edge } \\
\text { Insulation } \\
\end{array}$ & Option 2 & $\begin{array}{l}\text { Option } 2 \\
\text { with } \\
\text { Solar } \\
\text { PV }\end{array}$ \\
\hline $\begin{array}{c}\text { Lighting and } \\
\text { Appliances }\end{array}$ & $\begin{array}{c}\text { Gas appliances, } \\
\text { no ENERGY } \\
\text { STAR }\end{array}$ & $\begin{array}{c}\text { Gas appliances, } \\
\text { ENERGY } \\
\text { STAR, } 10 \% \\
\text { fluorescent } \\
\text { lighting }\end{array}$ & $\begin{array}{c}\text { Gas appliances, } \\
\text { ENERGY } \\
\text { STAR, } 60 \% \\
\text { fluorescent } \\
\text { lighting }\end{array}$ & $\begin{array}{c}\text { Gas appliances, } \\
\text { ENERGY } \\
\text { STAR, } 60 \% \\
\text { fluorescent } \\
\text { lighting }\end{array}$ & $\begin{array}{c}\text { Gas appliances, } \\
\text { ENERGY } \\
\text { STAR, } 80 \% \\
\text { fluorescent } \\
\text { lighting }\end{array}$ & $\begin{array}{c}\text { Gas appliances, } \\
\text { ENERGY } \\
\text { STAR, } 80 \% \\
\text { fluorescent } \\
\text { lighting }\end{array}$ & $\begin{array}{l}\text { Gas appliances, } \\
\text { ENERGY STAR, } \\
80 \% \text { fluorescent } \\
\text { lighting }\end{array}$ & $\begin{array}{l}\text { Gas appliances, } \\
\text { ENERGY STAR, } \\
\text { 80\% fluorescent } \\
\text { lighting }\end{array}$ \\
\hline PV & None & None & None & None & None & None & None & $1.1-\mathrm{kW}$ system \\
\hline $\begin{array}{c}\text { Source } \\
\text { Energy Use }\end{array}$ & 202 & 186 & 153 & 139 & 138 & 126 & 113 & 92 \\
\hline HERS Index & 97 & 89 & 68 & 62 & 60 & 56 & 45 & 37 \\
\hline $\begin{array}{c}\text { Estimated } \\
\text { Annual } \\
\text { Operating } \\
\text { Cost }^{\mathrm{a}}\end{array}$ & $\$ 2,217$ & $\$ 1,968$ & $\$ 1,590$ & $\$ 1,464$ & $\$ 1,435$ & $\$ 1,330$ & $\$ 1,192$ & $\$ 996$ \\
\hline
\end{tabular}

Notes: SHGC, solar heat gain coefficient; $\mathrm{ACH}_{50}$, air changes per hour at 50 Pascals; AFUE, annual fuel utilization efficiency; SEER, seasonal energy efficiency ratio; $\mathrm{EF}$, energy factor; $\mathrm{PV}$, photovoltaics.

${ }^{a}$ Utility rates used for the estimated annual operating cost were based on electricity from the City of Roseville and natural gas from the Pacific Gas and Electric Company, as follows.

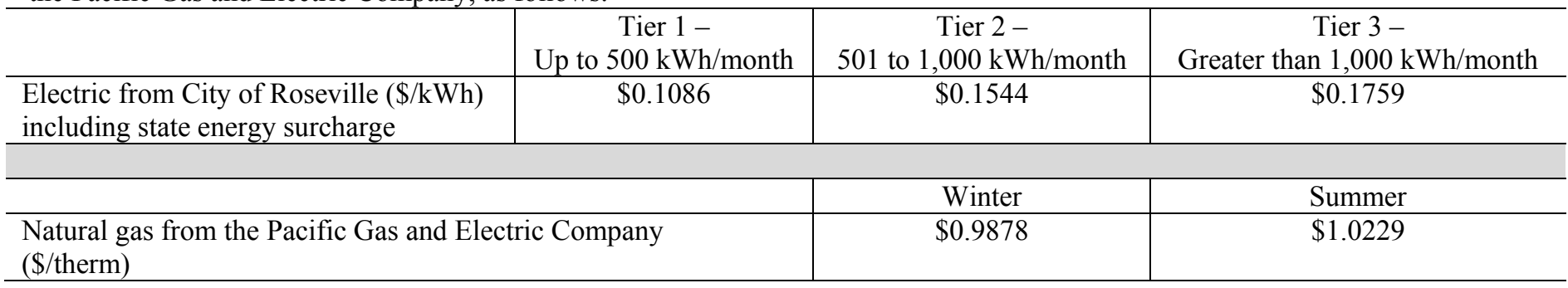




\subsubsection{Strategy for Locating Ductwork in Conditioned Space}

As a result of the increased benefits in energy savings, Option 2 was chosen for the enclosure specification. Then attention turned to location of insulation and air sealing in the attic, as well as the specific strategy to ensure placement of the mechanical equipment and ductwork inside conditioned space. This was part of a long, iterative design process among the builder, IBACOS, and several of the trade contractors, including framing, insulation, and mechanical. A high priority for the builder was to use this project as an opportunity to evaluate the most costeffective approach with the fewest design modifications. Table 2 provides a sample of the modeling work performed using EnergyGauge USA that IBACOS completed to represent the source energy and operational cost savings associated with bringing ductwork inside conditioned space. The results show an anticipated source energy savings of $11 \mathrm{MMBtu} / \mathrm{yr}$ and approximately $\$ 116$ savings in annual operating costs. Note that the values in Table 2 are not directly comparable to the values in Table 1 due to the use of two different modeling programs.

Table 2. Sample of Modeling Results from Mechanical Equipment and Ductwork Location Evaluation

\begin{tabular}{c|c|c}
\hline & $\begin{array}{c}\text { Option 2 Package From } \\
\text { Table 1-Mechanical } \\
\text { Equipment and } \\
\text { Ductwork in the Vented } \\
\text { Attic }\end{array}$ & $\begin{array}{c}\text { Option 2 Package From } \\
\text { Table 1-Mechanical } \\
\text { Equipment and } \\
\text { Ductwork Inside } \\
\text { Conditioned Space }\end{array}$ \\
\hline $\begin{array}{c}\text { Source Energy Use } \\
\text { (MMBtu/yr) }\end{array}$ & 123 & 112 \\
HERS Index & 54 & 52 \\
\hline $\begin{array}{c}\text { Estimated Annual } \\
\text { Operating Costs }\end{array}$ & $\$ 1,274$ & $\$ 1,158$ \\
\hline
\end{tabular}

IBACOS has significant experience working with other builder partners in bringing mechanical systems and ductwork inside conditioned space through the use of either cathedralized attic spaces or dropping bulkheads below the insulated ceiling plane. However, the builder stated that neither approach would be acceptable for its product line. Cathedralizing the insulation in the attic space (i.e., locating it at the underside of the roof deck rather than along the attic floor) would increase the total amount of insulation needed due to the increased surface area that would have to be covered, ultimately resulting in higher material costs. Additionally, changing the location of the insulation to the roof deck would increase the volume of conditioned space for the house but would not add usable square footage for the homeowner. The alternative of bringing the equipment and ductwork inside the conditioned space through dropped soffits or bulkheads below the ceiling plane was also deemed unacceptable by the builder.

In design meetings with the mechanical and framing trade contractors, the group discussed inverting the bulkhead or soffit space that typically would be installed below the ceiling plane and instead locating it at the attic floor, as shown in Figure 3 and Figure 4. 


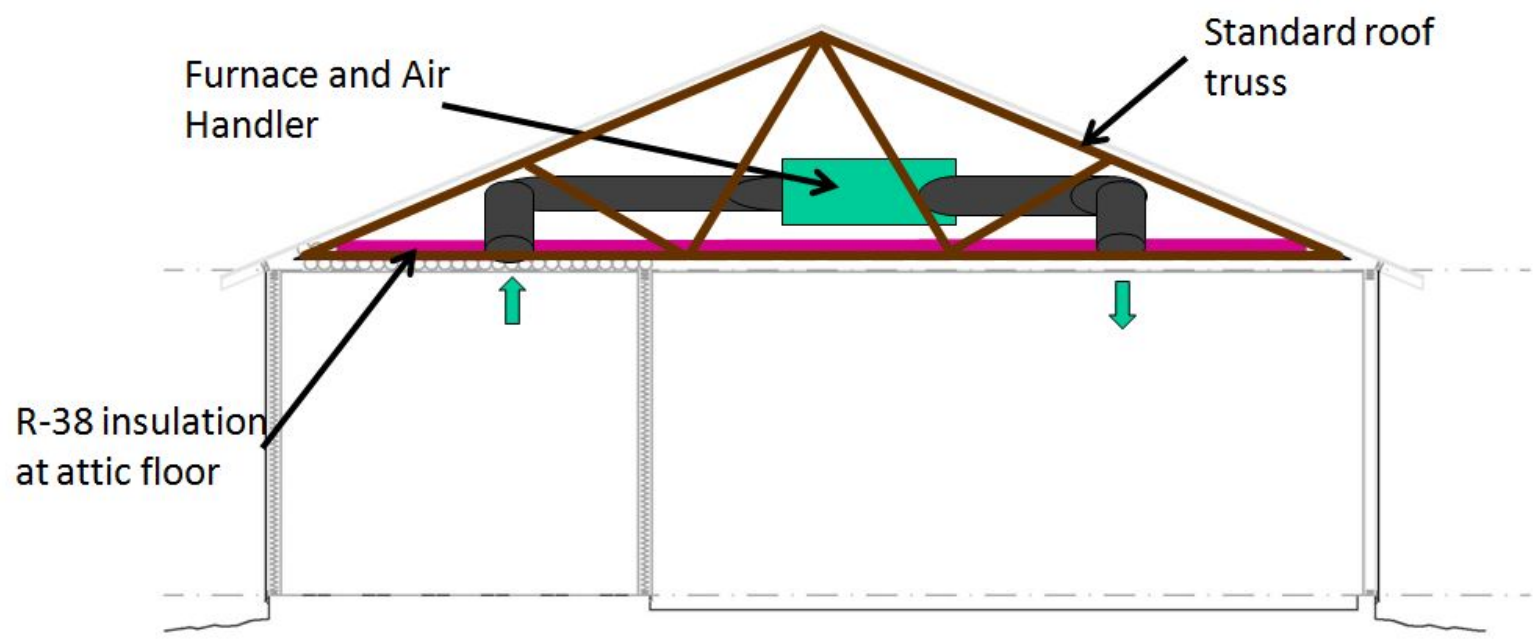

Figure 3. Mechanical equipment and ductwork within unconditioned space of the vented attic

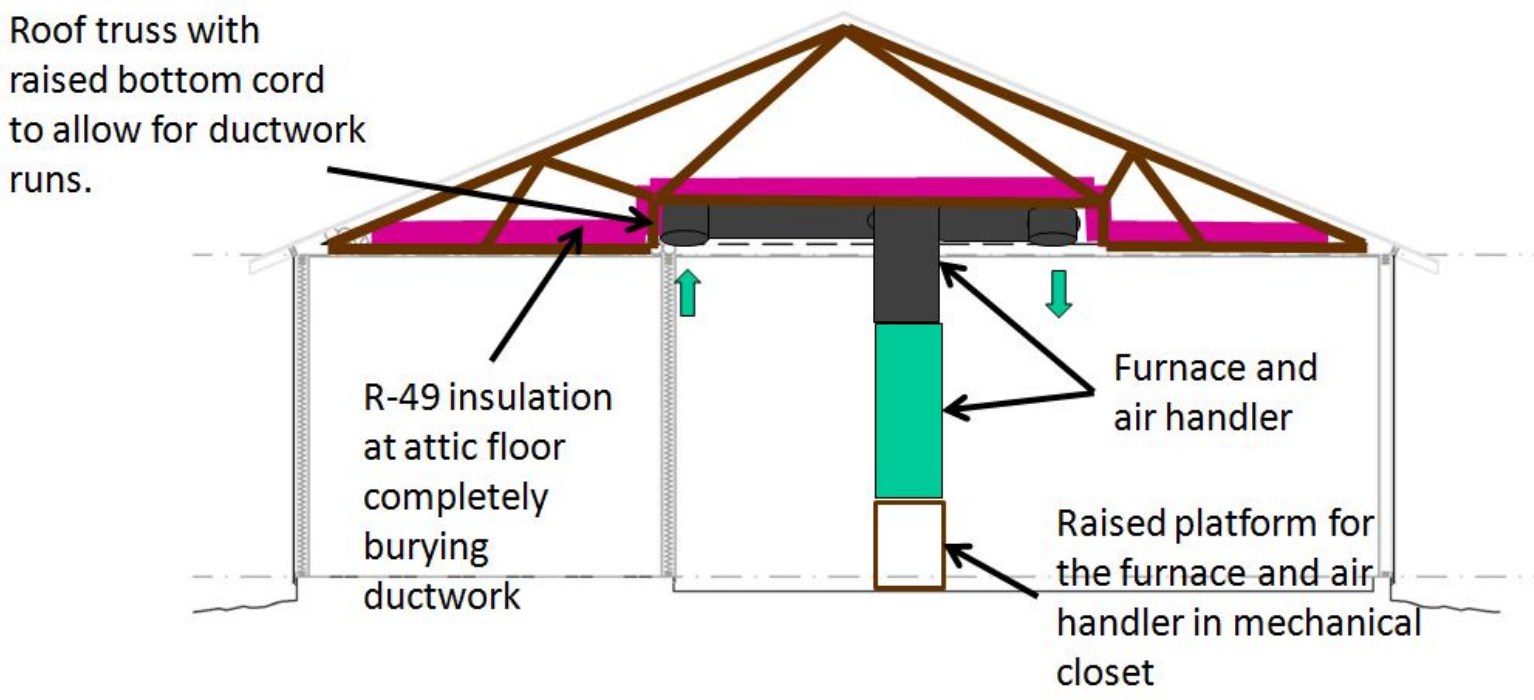

Figure 4. Mechanical equipment and ductwork within the semiconditioned bulkhead space at the floor of the vented attic

For the inverted bulkhead approach to be considered for this test house project, the team outlined several design parameters that had to be met, including that the redesigned truss not affect the bearing location at the footing level. If structural bearing supports had to be relocated, this would require an engineer to reevaluate the structural package for the home, and the plans would need to be resubmitted to the township for review. In addition, the trusses would need to create an unobstructed space to accommodate the largest diameter insulated flexible ductwork that was 
anticipated for use, based on the room-by-room heating and cooling load calculations for the house. In this case, a 12-in.-diameter duct with R-6 insulation was the largest specified.

The roof truss manufacturer also participated in the design discussions and was able to provide a proposed redesign of the roof truss within the time allotted. By modifying the original design (see Figure 5), the proposed design as shown in Figure 6 provided a centrally located chase along the floor of the attic. To provide the central bearing location that was consistent with the existing structural design for the home, a framing member was dropped from the truss web to bear on the interior load-bearing partition wall. Figure 7 shows in plan view the approximate area of the cavity created by the new truss design and the ductwork layout. Not all the duct runs terminate within the centralized bulkhead. Due to the layout of the girder trusses, the bulkhead area was limited to the area shown. To maintain register locations at the ceiling plane, rather than dropping down into a high sidewall register (a recommended change for future projects), some runs had to penetrate through the side of the bulkhead and extend up to $7 \mathrm{ft}$ outside of it. Approximately $15 \%$ of the total installed duct length was outside conditioned space; this was not accounted for in the final BEopt models because that software does not allow for a fractional ductwork location.

Although not all of the ductwork fit in the area of the cavity, care was taken during installation to ensure that any ductwork passing out of the cavity (see Figure 8) was well sealed at the penetration, and the portions outside the cavity were buried in the full depth of loose-fill insulation.

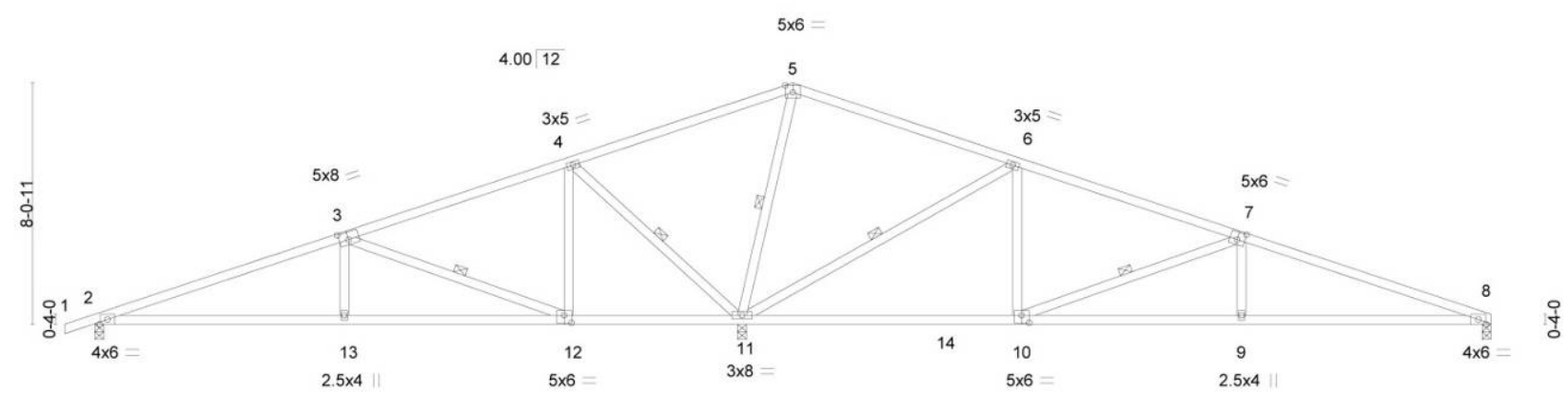

Figure 5. Standard roof truss for the builder's Plan 4 houses 


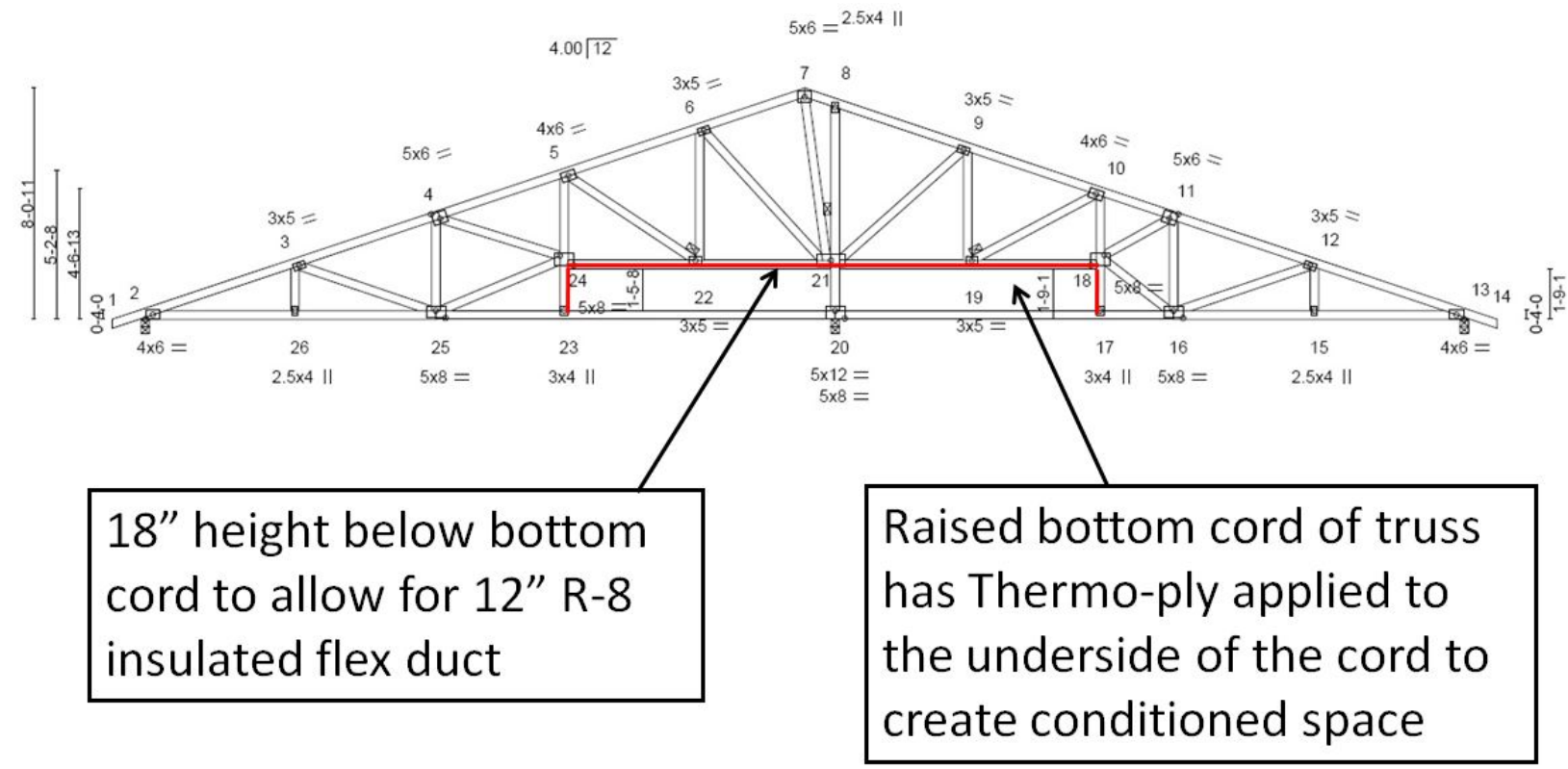

Figure 6. Modified roof truss for the Plan 4 test house, which provides a chase for ductwork at the ceiling plane and has 16 -in. raised heels along the perimeter 


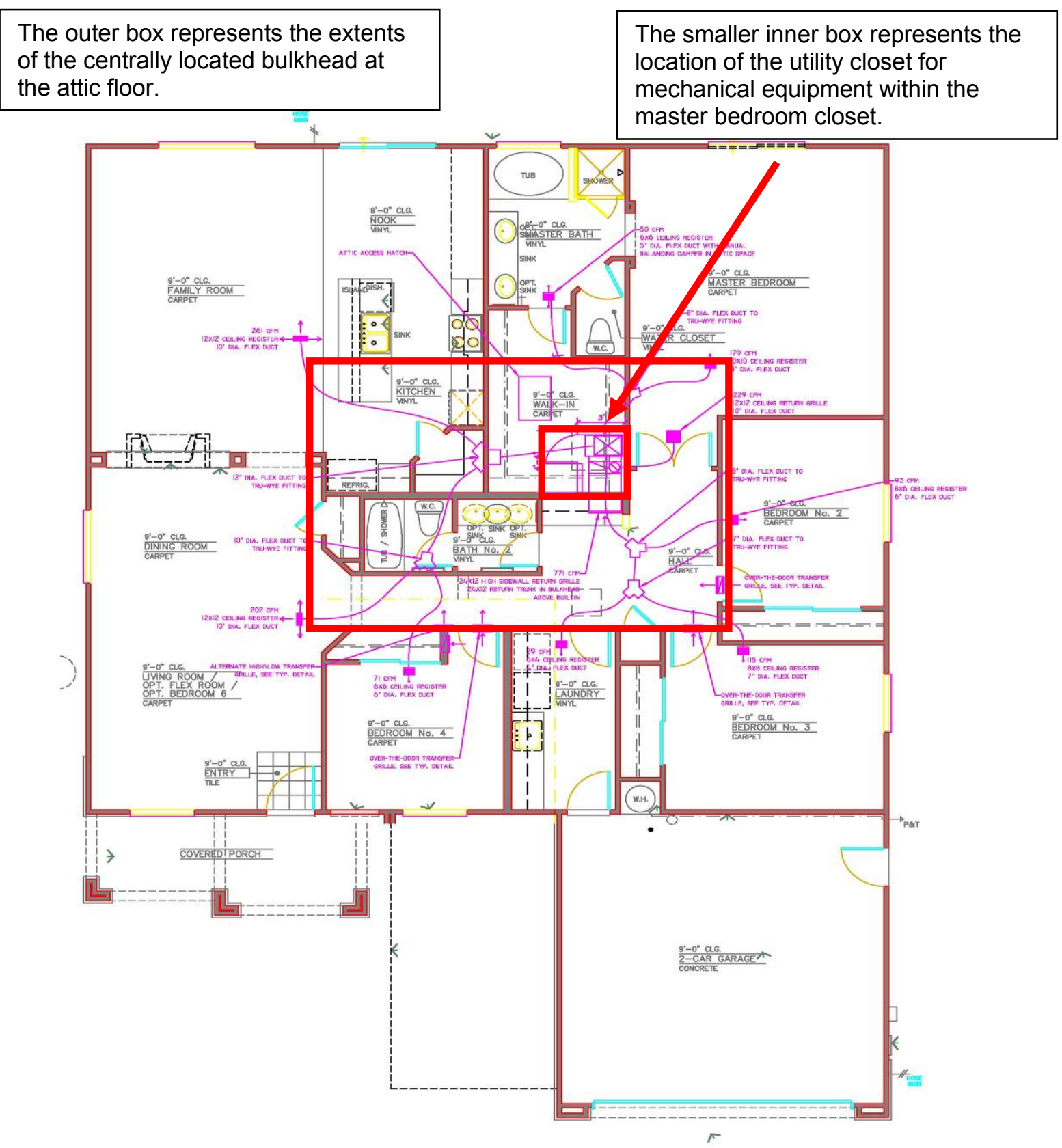

Figure 7. Final layout of the centrally located bulkhead and mechanical equipment inside a closet 


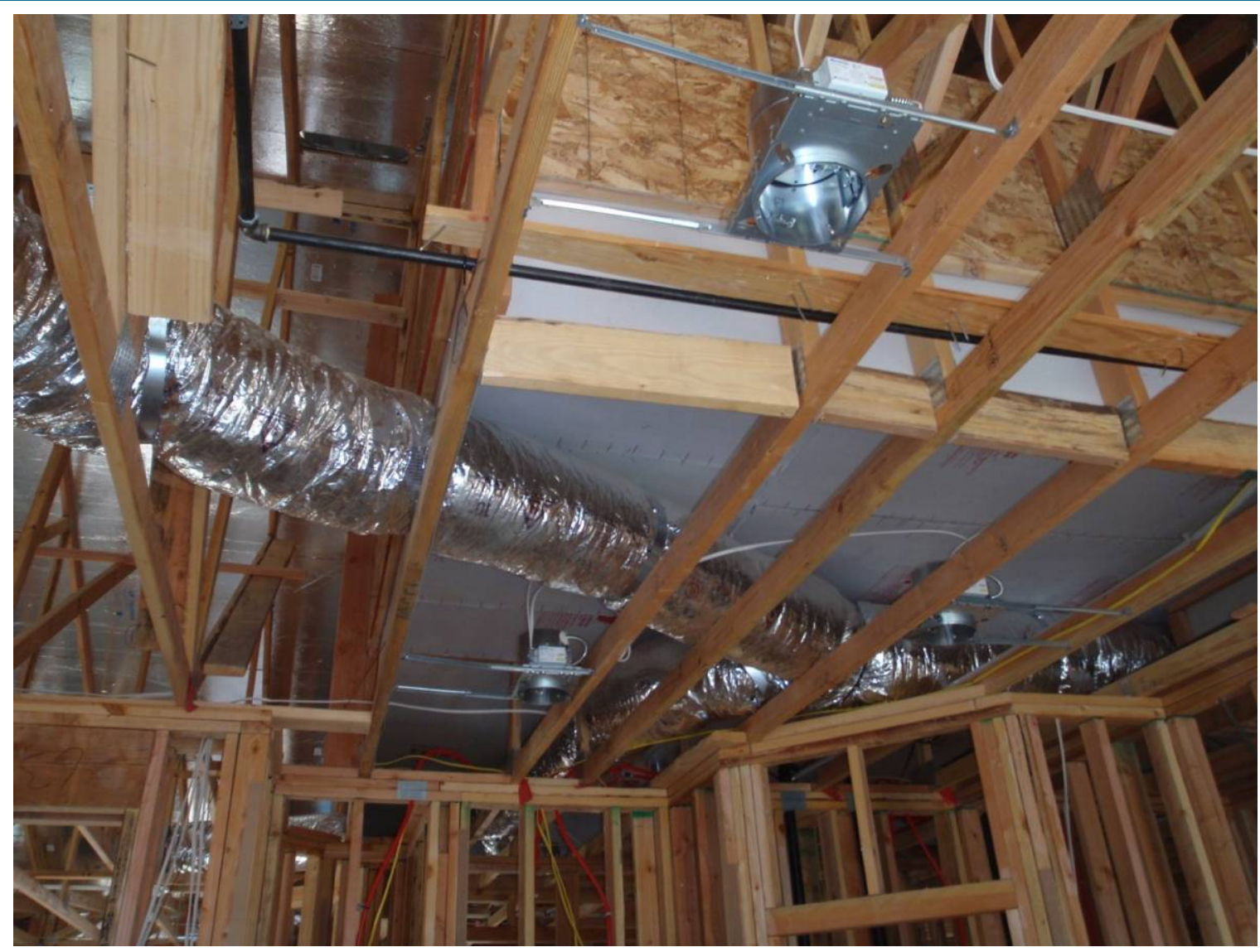

Figure 8. Ductwork centrally distributed within the conditioned space of the bulkhead at the attic floor

\subsection{Whole-House Energy Modeling}

IBACOS used a combination of REM/Rate and EnergyGauge USA to evaluate the whole-house energy consumption of the prototype during the design process. As a result of the design efforts outlined in Section 2.1 above, the thermal envelope was changed from the standard specifications to include high performance construction features such as 2 in. of slab edge insulation, R-15 wall insulation, 16-in. raised heel trusses to accommodate R-38 insulation on the attic floor, and higher performing windows. Mechanical equipment with improved rated efficiency was incorporated and located in conditioned space via the use of a bulkhead built into the roof trusses. Additionally during construction, the decision was made to increase the attic insulation to R-49 in areas of the attic with sufficient clearance. Furthermore, the PV system was upgraded from the originally specified $1.1-\mathrm{kW}$ system to a $2.4-\mathrm{kW}$ system. These as-built specifications were used in BEopt models for BA program purposes. Energy modeling using BEopt Version 1.3 was performed based on the specifications for the as-built prototype and the builder's standard shown in Table 3. 
Table 3. Comparison of Standard Versus Prototype House Specifications

\begin{tabular}{|c|c|c|}
\hline Component & 2011 Builder Standard & Prototype House \\
\hline Concrete Slab & Uninsulated & R-10 vertical slab edge insulation \\
\hline Exterior Walls & $\begin{array}{c}2 \times 4 \text { 16-in. o.c. R-13 with } \\
\text { R-3 sheathing }\end{array}$ & $\begin{array}{c}2 \times 4 \text { 16-in. o.c R-15 with } \\
\text { R-3 sheathing }\end{array}$ \\
\hline Roof & $\begin{array}{c}\text { Attic floor R-30 with radiant } \\
\text { barrier }\end{array}$ & $\begin{array}{l}\text { Attic floor R- } 49 \text { with radiant } \\
\text { barrier, with built-in bulkhead to } \\
\text { accommodate ductwork below } \\
\text { insulation and raised heel trusses }\end{array}$ \\
\hline Exterior Doors & $\mathrm{R}-4$ & $\mathrm{R}-4$ \\
\hline Windows & $\mathrm{U}=0.35, \mathrm{SHGC}=0.30$ & $\mathrm{U}=0.28, \mathrm{SHGC}=0.26$ \\
\hline Building Airtightness & $3.0 \mathrm{ACH}_{50}$ & $\begin{array}{l}2.45 \mathrm{ACH}_{50} \text { tested } \\
\left(1.7 \mathrm{ACH}_{50} \text { target }\right)\end{array}$ \\
\hline Mechanical Ventilation & $\begin{array}{l}\text { Exhaust only per ASHRAE } \\
62.2 \text { (ASHRAE 2010a) }\end{array}$ & $\begin{array}{c}\text { AirCycler VS into return duct with } \\
\text { AirCycler SmartExhaust switch in } \\
\text { bathrooms }\end{array}$ \\
\hline Heating & $\begin{array}{l}\text { 80-AFUE natural gas furnace } \\
\text { located in unconditioned attic }\end{array}$ & $\begin{array}{l}\text { 95-AFUE natural gas furnace } \\
\text { located in mechanical closet in } \\
\text { master bedroom closet }\end{array}$ \\
\hline Cooling & 13 SEER & 16 SEER \\
\hline Ductwork & $\mathrm{R}-6$ in unconditioned space & $\begin{array}{l}\text { R-6 in conditioned bulkhead, R- } 8 \\
\text { in unconditioned space buried } \\
\text { under R-49 insulation; } 2.4 \% \text { total } \\
\text { leakage compared to fan flow } \\
\text { (measured results) }\end{array}$ \\
\hline Water Heater & 50 -gal gas, $\mathrm{EF}=0.6$ & Tankless gas, $\mathrm{EF}=0.94$ \\
\hline Appliances & $\begin{array}{c}\text { ENERGY STAR refrigerator } \\
\text { and dishwasher }\end{array}$ & $\begin{array}{l}\text { ENERGY STAR refrigerator and } \\
\text { dishwasher }\end{array}$ \\
\hline Fluorescent Lighting & $60 \%$ & $80 \%$ \\
\hline PV & None & $2.4 \mathrm{~kW}$ \\
\hline $\begin{array}{c}\text { \% Better than BA } \\
\text { House Simulation } \\
\text { Protocols (Hendron and } \\
\text { Engebrecht 2010) }\end{array}$ & $12.0 \%$ & $\begin{array}{l}35 \% \text { without PV, } \\
60 \% \text { with PV }\end{array}$ \\
\hline
\end{tabular}

BEopt models predicted that the builder's standard inputs would provide a savings of $11.8 \%$ relative to the BA House Simulation Protocols (Hendron and Engebrecht 2010), whereas the prototype house specifications provided savings of $35 \%$ without PV and $60 \%$ with PV (both relative to the BA House Simulation Protocols) (Hendron and Engebrecht 2010). Figure 9 illustrates this comparison. 


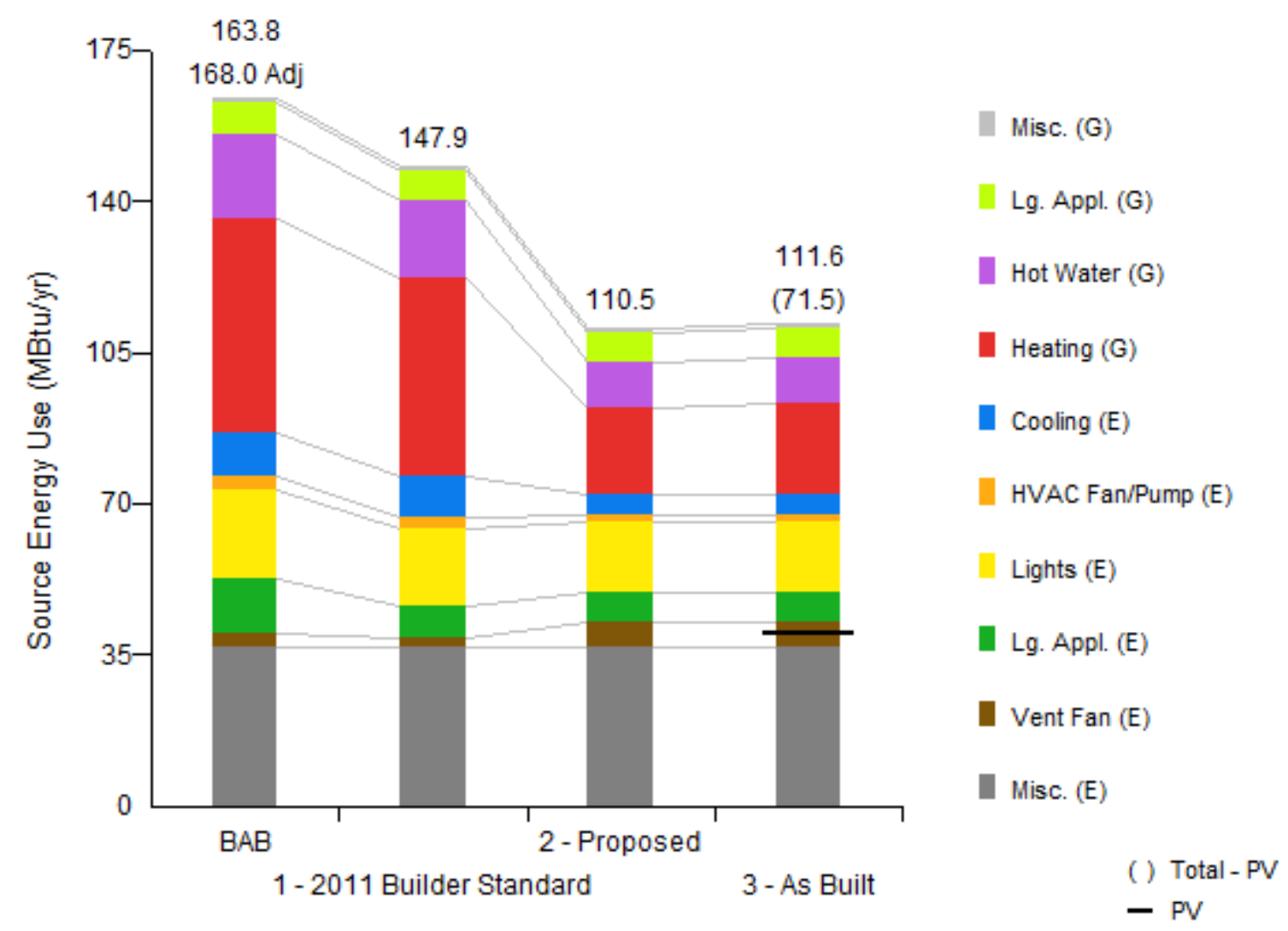

Figure 9. Output from BEopt source energy modeling by subcategory

\subsection{Test Plan Development}

After the test house was designed and the modeling was completed, a field test plan was developed to answer the research questions that arose during the design development process.

\subsubsection{Research Questions}

Research questions for this test house project focused on measuring the performance of the proposed space conditioning system and specifically the capacity of the system to maintain acceptable levels of indoor temperature and relative humidity. Data were collected on the performance of both the equipment and distribution ducts.

Much resistance to the load calculation, system sizing, and design strategies proposed for this test house was encountered in discussions with the heating, ventilation, and air conditioning (HVAC) trade contractor and mechanical system designer for this project. Contractors appear to be unfamiliar with the centrally located system using compact duct runs that throw air toward exterior walls. Thus, the contractors are reluctant to assume the liability of the performance of these systems because the systems deviate significantly from their standard system design approach. 
One of the main goals of the project was to involve the HVAC contractor and the mechanical system designer throughout the design, installation, and testing process of the space conditioning system to demonstrate to them the cost savings and performance benefits of these types of systems. The hope is that they will incorporate these practices into their system designs in the future.

The following questions were developed to be answered via short-term testing and long-term monitoring:

- How effective is the proposed space conditioning system at maintaining Air Conditioning Contractors of America (ACCA) Manual RS standards for temperature uniformity (Rutkowski 1997) in several rooms of the house: the master bedroom, the kitchen/family room, and one additional bedroom?

- What is the difference in temperature in the insulated bulkhead cavity compared to the uninsulated attic?

- What are the delivered supply temperatures at each register, and how long after system startup does it take for the temperature of the supply air measured at the point of delivery (register) to reach the temperature measured at the main plenum?

- How do temperature and relative humidity vary in each measured room from the temperature at the thermostat?

- Near a window or sliding door?

- Near an opaque wall?

- In the center of a room?

○ What is the temperature distribution in each measured room using ceiling supply registers located closer to the center of the house?

○ How do temperature and relative humidity levels vary with system runtime?

$\circ$ What is the homeowner perception of temperature and relative humidity levels in the house?

- How does the actual measured energy consumption of four major subcategories (heating; cooling; hot water; and lighting, appliances, and miscellaneous electric loads) compare to the projected energy consumption using BEopt when actual weather and operating conditions are normalized? Is there any clear evidence that these differences are due to weather, occupant behavior, modeling errors, or system performance issues?

Although answering all of these questions will require long-term monitoring, the following short-term characterization tests as detailed in Table 4 are necessary to understand the long-term results. 
Table 4. Research Measurements and Equipment for Short-Term Characterization Tests

\begin{tabular}{c|l}
\hline Measurement & \multicolumn{1}{c}{ Equipment } \\
\hline $\begin{array}{c}\text { Building Airtightness } \\
\text { Room-by-Room Airflows }\end{array}$ & Energy Conservatory Blower Door \\
\hline $\begin{array}{c}\text { Air Leakage at Recessed Cans and } \\
\text { Wall Penetrations }\end{array}$ & Energy Conservatory Duct Blaster \\
\hline $\begin{array}{c}\text { Room-to-Room Pressure Balancing } \\
\text { Infrared (IR) Flow Visualization }\end{array}$ & DLIR T400 IR thermal imaging camera \\
\hline $\begin{array}{c}\text { Room Temperature Uniformity } \\
\text { Measurements }\end{array}$ & $\begin{array}{l}\text { Campbell Scientific CR1000 data logger } \\
\text { with unshielded thermocouples mounted } \\
\text { on wooden test stands }\end{array}$ \\
\hline
\end{tabular}

Short-term test results are detailed in the following sections. Long-term monitoring will be detailed in a future report after at least 1 year of monitored data has been collected. 


\section{Short-Term Tests}

\subsection{Room-by-Room Supply Register Airflow}

\subsubsection{Methods}

The airflow from each supply register in each room was measured in cooling mode using a calibrated low-flow balometer as shown in Figure 10. The readings are documented for comparison to the design values for airflow. If necessary, flows can be adjusted and balanced to meet the design values through the use of balancing dampers in the ductwork. Flow hood measurements at each register will quantify airflow at those registers and will allow a comparison to be made against design values and to determine the existence of any potential low airflow situations that may affect occupant comfort.

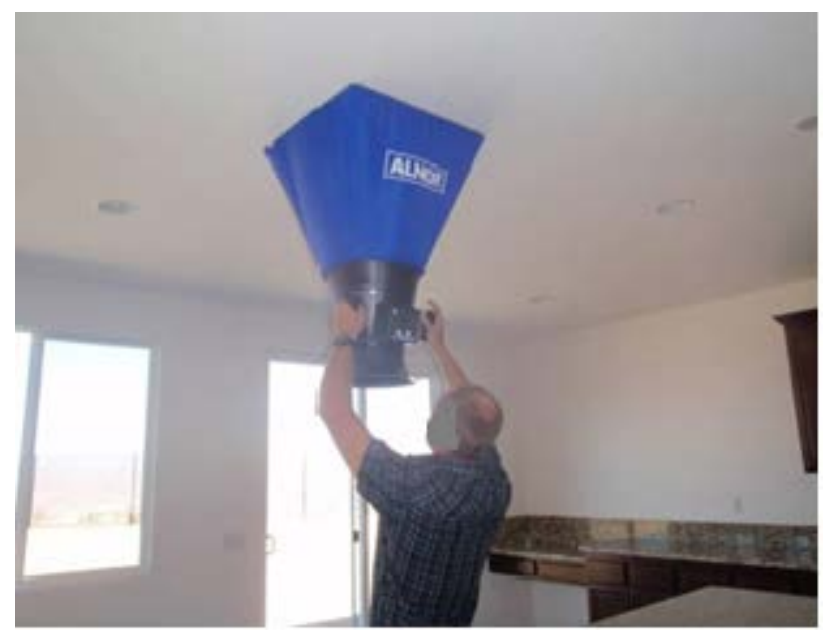

Figure 10. Low-flow balometer testing

\subsubsection{Results}

Airflow from each supply register in each room was measured in cooling mode using a calibrated low-flow balometer. Table 5 lists the results. Variations from design values ranged from $1.4 \%$ to $110 \%$. Although measured flows for the kitchen/family room area and master bedroom were substantially different from the design values, they were still within the ACCA Standard 5 requirements of a difference of no more than $20 \%$ or 25 CFM (whichever is greater) between design and measured flow rates (ACCA 2010). The laundry room was outside these limits, with flow $110 \%$ ( 32 CFM) greater than design. Balancing of the flows could not be completed due to the location of balancing dampers in the bulkhead space, which at the time of flow testing had already been rendered inaccessible by the installation of the ceiling drywall. Airflow at the master bathroom was not measured because the register location was overlooked during testing. 
Table 5. Pressure Balancing Results for Each Room

\begin{tabular}{c|c|c|c|}
\hline Location & $\begin{array}{c}\text { Design } \\
\text { Airflows }\end{array}$ & $\begin{array}{c}\text { Measured } \\
\text { Airflows }\end{array}$ & $\begin{array}{c}\text { \% of } \\
\text { Deviation } \\
\text { from Design }\end{array}$ \\
\hline Master Bedroom & 229 & 270 & $\mathbf{1 8 \%}$ \\
\hline Bedroom 1 & 93 & 87 & $-\mathbf{6 \%}$ \\
\hline Bedroom 2 & 115 & 107 & $-\mathbf{7 \%}$ \\
\hline Laundry & 29 & 61 & $\mathbf{1 1 0 \%}$ \\
\hline Office/Den & 71 & 72 & $\mathbf{1 . 4 \%}$ \\
\hline Living Room & 202 & 210 & $\mathbf{4 \%}$ \\
\hline Kitchen/Family Room Area & 261 & 311 & $\mathbf{1 9 \%}$ \\
\hline Master Bathroom & $\mathbf{5 0}$ & - & - \\
\hline
\end{tabular}

\subsubsection{Discussion}

Although balancing dampers were specified in the HVAC plans and were installed in the test house, due to the installation of drywall prior to the installation of the furnace/air-handler unit (AHU), the balancing dampers were unable to be used to balance the flow. This is unique to the design strategy of creating an airtight box around the ductwork, which rendered the balancing dampers inaccessible; however, access to balancing dampers can be difficult in any attic installation situation. In the future, if this design strategy of creating an airtight box around ductwork to place it inside conditioned space is used, the order of installation must be considered to accommodate system balancing, or provisions should be made to facilitate access to the dampers in the bulkhead space. The design flows compared to the measured flows indicate a 68 CFM increase above design airflows, indicating that the proper fan speed had not been selected in the furnace/AHU.

\subsection{Duct Air Leakage}

\subsubsection{Methods}

The tightness of the air distribution system was tested with a duct blaster to determine the total air leakage in the system and, in conjunction with the blower door test, to determine air leakage to the outdoors. The amount of air leakage found will allow the assessment of the performance of the capacity of the air distribution system for delivering and drawing air into the house.

\subsubsection{Results}

Duct leakage tests were performed to determine total air leakage from the distribution system as a percentage of total system airflow. Table 6 shows the results. Duct leakage testing was also performed in conjunction with the blower door test to determine the amount of air leakage from the ductwork to the outdoors. Duct leakage to the outdoors was relatively low.

Table 6. Duct Air Leakage Test Results

\begin{tabular}{c|c}
\hline Performance Metric & Results \\
\hline House Size & $2,311-\mathrm{ft}^{2}$ finished area \\
Duct Leakage & $2.4 \%$ \\
\hline
\end{tabular}




\subsubsection{Discussion}

Duct air leakage was within the CEC 2008 Building Energy Efficiency Standards (CEC 2010), validating the measures taken to reduce the duct length and to locate the ductwork within conditioned space.

\subsection{Whole-Building Air Leakage}

\subsubsection{Methods}

To evaluate the airtightness performance of the building enclosure, a test using a blower door was conducted after the house was completed. The test measured the number of ACH under negative pressure for the house, and the test values can be compared to the benchmark values.

An intermediate blower door test (shown in Figure 11) was performed after drywall was installed but before trim, floors, and ceiling penetrations were sealed to measure the amount of air leakage in the whole house.

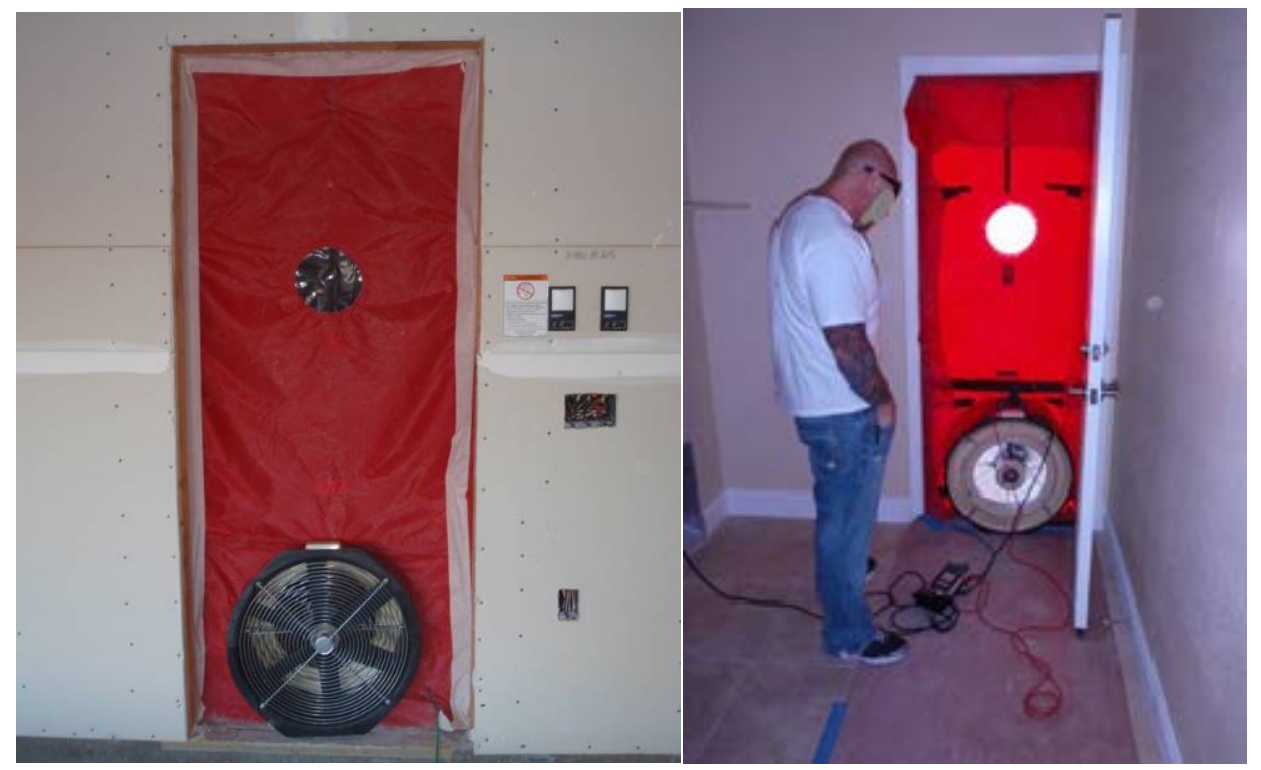

Figure 11. Blower door testing

\subsubsection{Results}

An intermediate test to measure the house air leakage rate at $50 \mathrm{~Pa}$ depressurization was conducted when the house was mostly complete, except that all ceiling penetrations were unsealed.

Final testing after sealing all ceiling penetrations revealed an improvement for the completed house. Table 7 compares these results to the intermediate test results. 
Table 7. Characterization Testing: House Leakage

\begin{tabular}{c|c|c}
\hline Performance & \multicolumn{2}{|c}{ Results } \\
\hline House Size & \multicolumn{2}{|c}{$2,311-\mathrm{ft}^{2}$ finished area } \\
House Volume & \multicolumn{2}{|c}{$20,799 \mathrm{ft}^{3}$} \\
& Test $1^{\mathrm{a}}$ & Final \\
Infiltration & $1,400 \mathrm{cfm}_{50}$ & $850 \mathrm{cfm}_{50}$ \\
& $4.03 \mathrm{ACH}_{50}$ & $2.45 \mathrm{ACH}_{50}$ \\
\hline
\end{tabular}

${ }^{a}$ Prior to trim and sealing of all penetrations but after sheetrock installation

\subsubsection{Discussion}

Whole-building air leakage improved considerably after air sealing all penetrations through the drywall. The final value of $2.45 \mathrm{ACH}_{50}$ is greater than the target value of $1.7 \mathrm{ACH}_{50}$. Possible reasons for the failure to meet this goal include recessed light fixture and wall penetration leakage. Despite attempts made at sealing them, they still showed significant air leakage levels, as discussed below in Section 3.4. The exhaust fans also represented a source of air leakage.

Although it was difficult to get a laborer into the attic to perform the air sealing because that effort was a new venture, a significant decrease in air leakage was possible. Using two people to perform the installation could have sped the installation time to enable one person to move the equipment, hose, and light while the other person performed the air sealing. The significant drop in air leakage is a result of this sealing process.

\subsection{Recessed Light Fixture and Wall Penetration Air Leakage}

\subsubsection{Methods}

Additional testing was conducted during blower door testing to measure air leakage around recessed light fixtures and wall penetration air leakage. A pressure pan and digital manometer were used to conduct testing at recessed light fixtures, wall outlets, and switches.

\subsubsection{Results}

Additional testing was conducted during the blower door testing to document the specific air leakage contribution of various penetrations. The insulation-contact-rated airtight recessed light fixtures ranged from 2 to $3 \mathrm{CFM}$ each; wall outlets and switches ranged from 1 to $13 \mathrm{CFM}$ each.

\subsubsection{Discussion}

The recessed light fixture and wall penetration air leakage levels remained significant even after air sealing was performed at the junction between the recessed light fixtures to the drywall and wire penetrations at the top plates.

Significant leakage through the outlets and switches remained, both on the interior partition walls and exterior walls. No sealing was performed at the switchbox; instead, rigorous air sealing was performed at the top plates of the interior walls. Blower door testing indicated that air leakage may be occurring to interior partition walls from the exterior wall via penetrations between the walls. Also, due to difficulty in accessing the top plate on the exterior wall of the house, sealing at this location may have been subpar. Spray foam was applied after the batts had been installed on the perimeter, which covered the top plate of the exterior wall that abutted the garage.

Lack of good connection between the drywall in the garage and the bottom plate contributed to significant air leakage into the house at that point. 
Due to the large number of outlets and switches, as well as low-voltage boxes, the total contribution to air leakage of the house was significant.

\subsection{Room-to-Room Pressure Balancing}

\subsubsection{Methods}

A digital manometer was used to measure the pressure difference between rooms with the doors closed to the central space. Readings were taken with the doors closed and the mechanical system operating at each room with transfer grilles over the doors. Readings can be compared to the benchmark values.

\subsubsection{Results}

Pressure readings were taken with the doors closed and the mechanical system operating. The pressure readings between the spaces were within desired results, varying between 0.1 to $0.3 \mathrm{~Pa}$.

\subsubsection{Discussion}

Pressure differences between individual rooms and the airspace containing the central return were acceptably low due to the use of over-the-door pressure relief grilles.

\subsection{Infrared Flow Visualization}

\subsubsection{Methods}

Flow visualization testing using an IR thermal imaging camera was conducted in the master bedroom to determine the temperature uniformity of those spaces provided by the compact duct system layout and the use of ceiling-mounted supply distribution.

Infrared cameras "see" the temperatures of surfaces but not air. For the camera to be able to see the flow pattern of the air, a "screen" was created from a 6-ft $\times 9$-ft black sheet of felt, mounted on two paint-roller extension poles and a shower rod, with sufficient clamps to hold the assembly together (see Figure 12). When this black felt screen was placed parallel to the primary flow path from the register, its surface temperature responded based on the temperature and flow pattern of the air leaving the supply register. Then IR pictures of the felt were taken to visually observe flow patterns. Test equipment consisted of an IR camera and the black felt screen assembly.

The purpose of this testing was to observe if flow from the ceiling-mounted registers located toward the interior walls could provide sufficient "throw" to ensure that conditioned air reached the exterior walls. Flow was observed in both the heating mode and the cooling mode. 


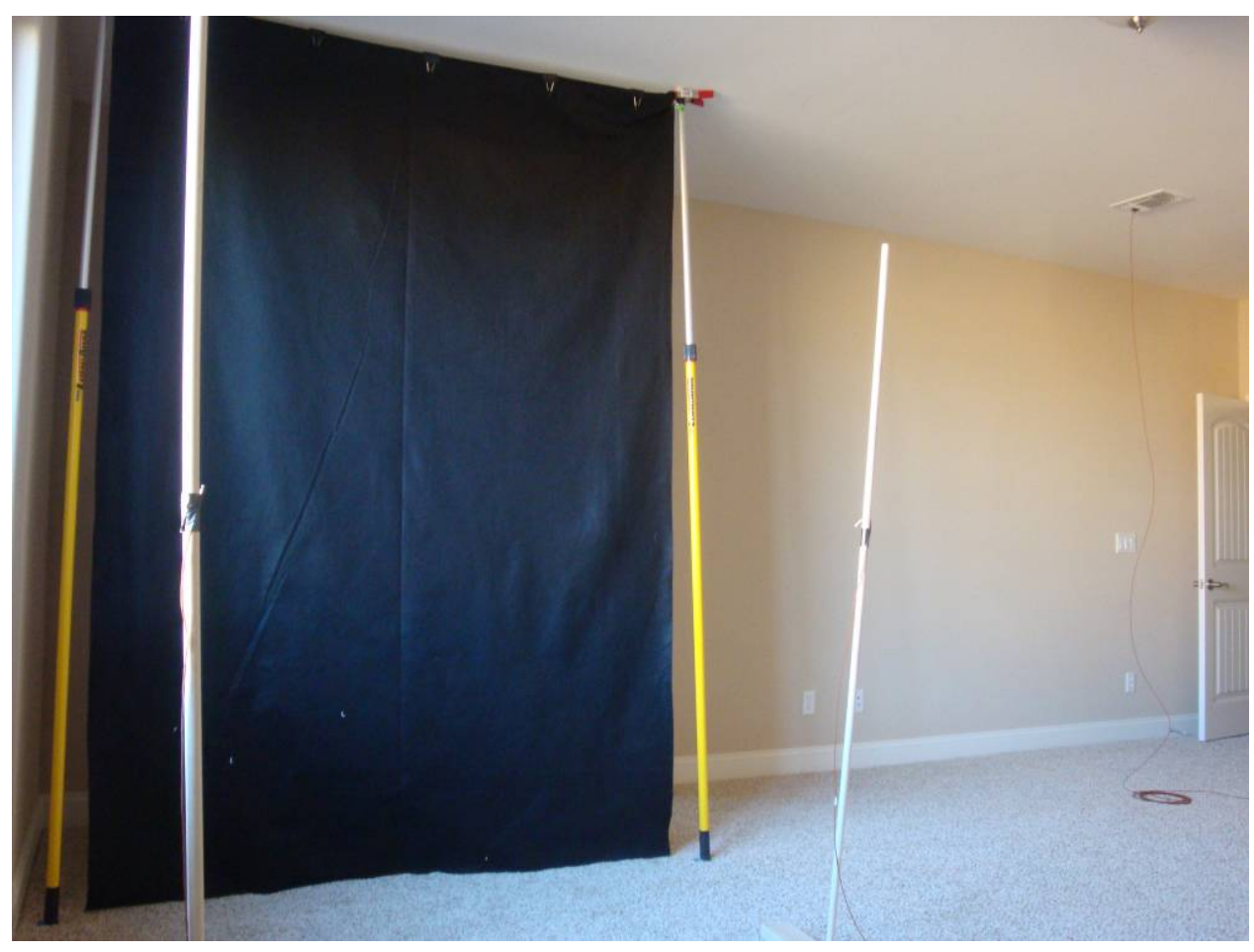

Figure 12. Black felt IR viewing screen positioned adjacent to an exterior wall and parallel to the primary register airflow path

\subsubsection{Results}

Conditions during the test were clear, $50^{\circ} \mathrm{F}$ outdoor temperature, and $70^{\circ} \mathrm{F}$ indoor temperature, and the testing was performed between 6:00 p.m. and 8:00 p.m. Because outdoor conditions were mild, it was possible to operate the HVAC system in both the heating mode and the cooling mode. During the cooling mode, the observed flow behavior from the register indicated that air was mixing uniformly upon leaving the register, as shown in Figure 13.

The flow in heating mode was observed to reach the exterior wall of the room, as shown in Figure 14 and Figure 15. Note that the use of a wide range for these two photos prevents sharp visual contrast between the hot and cool areas. However, significant stratification was observed, with an obvious layer of cooler air extending upward about $4 \mathrm{ft}$ from the floor. Further testing was performed in other rooms of the house (see Figure 16 and Figure 17) and revealed behavior consistent with that observed in the master bedroom. These measurements were taken by IR photographing of the walls of the house, revealing a clear pattern of stratification.

To help determine the cause of this behavior, IR photography during heating system operation also was measured in a nearby house built to the builder's typical practices with respect to the construction of the thermal enclosure and the placement of the HVAC registers. Both houses shared the same floor plan and orientation, and testing was performed after dark. Observations from the house built to the builder's typical standard showed the same behavior. No black felt setup was required in the nearby house because taking an IR picture of the walls was sufficient to observe the stratification. 
Research conducted by Straub (1957) indicates that this behavior is due to the ceiling location of the registers, along with the supply temperatures associated with a typical forced-air, fuel-fired space heating system. If supply temperatures were closer to the temperature of the air in the room, less stratification would be observed. Straub (1957) recommends that supply temperatures for ceiling registers be no greater than $100^{\circ} \mathrm{F}$ to prevent stratification similar to that observed at the Roseville test house.

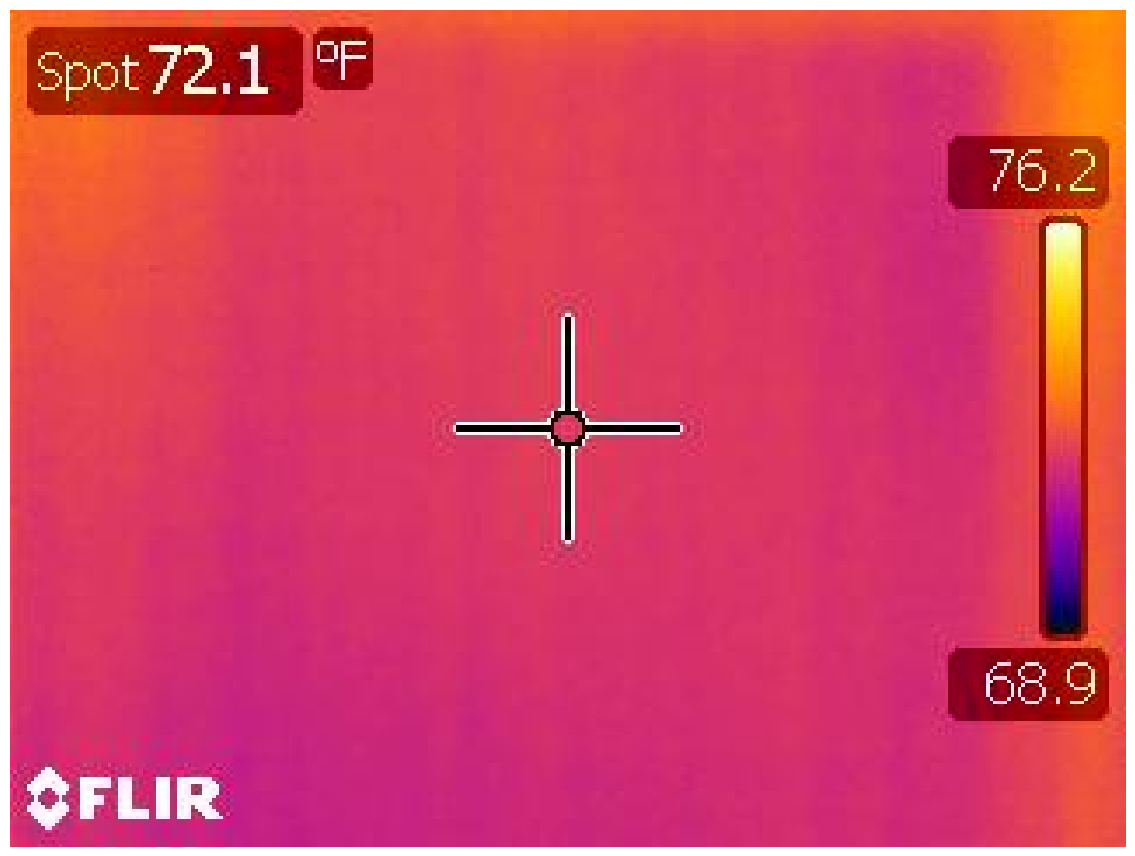

Figure 13. IR photo of black felt screen during cooling system operation (temperature scale in ${ }^{\circ} \mathrm{F}$ ) 


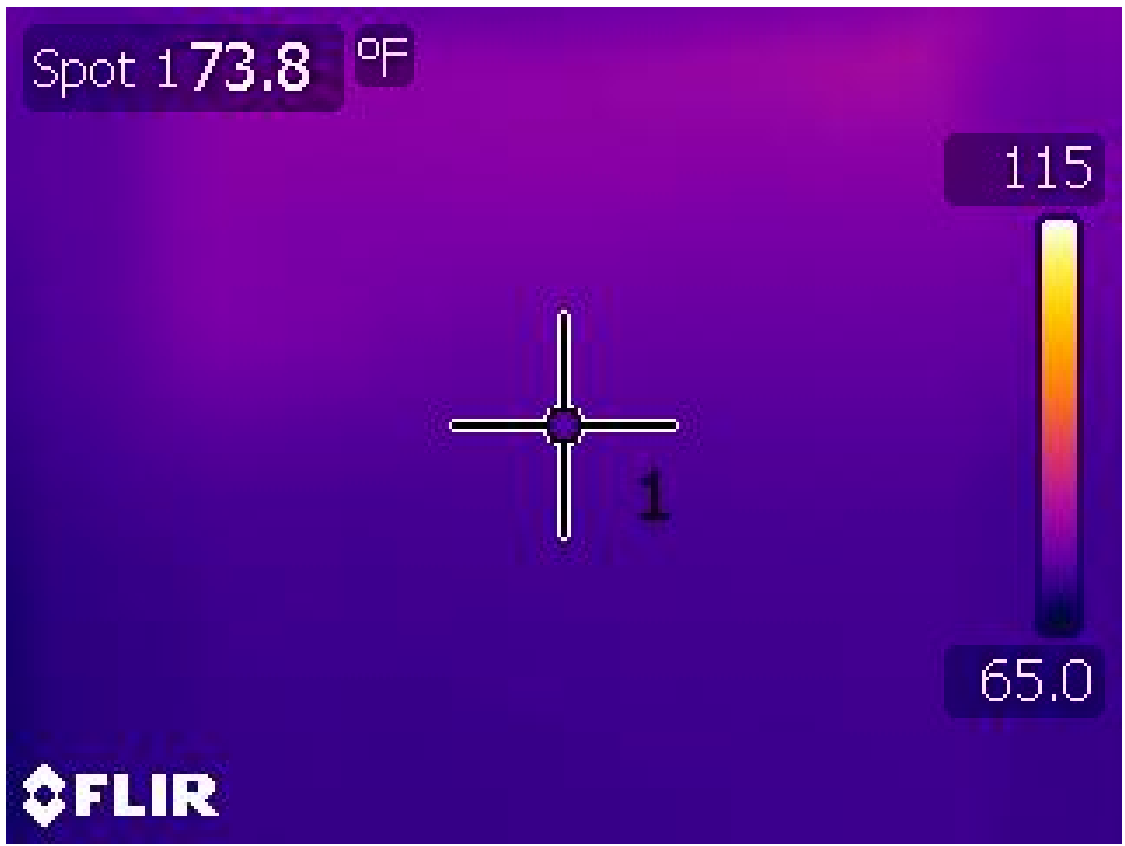

Figure 14. IR photo of black felt screen during heating system operation (temperature scale in ${ }^{\circ} \mathrm{F}$ )

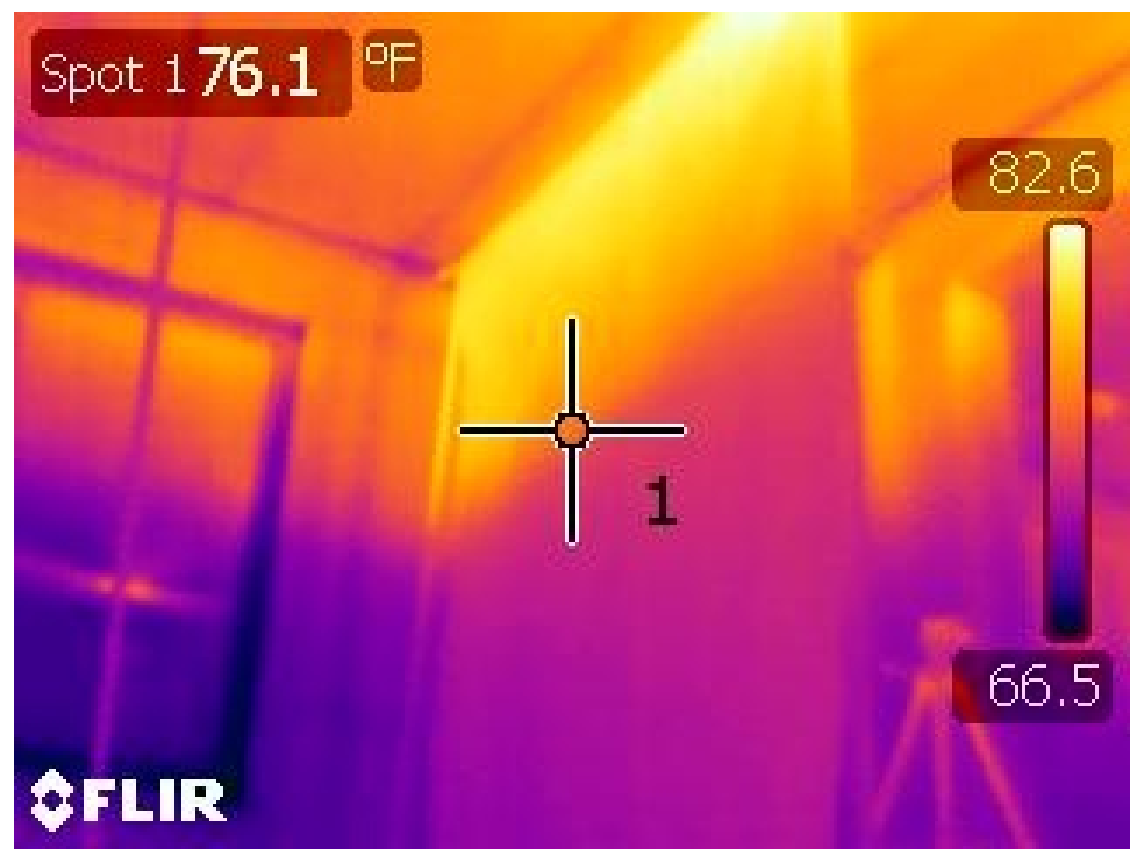

Figure 15. IR photo of black felt screen shortly after system turnoff, clearly showing stratification (temperature scale in ${ }^{\circ} \mathrm{F}$ ) 


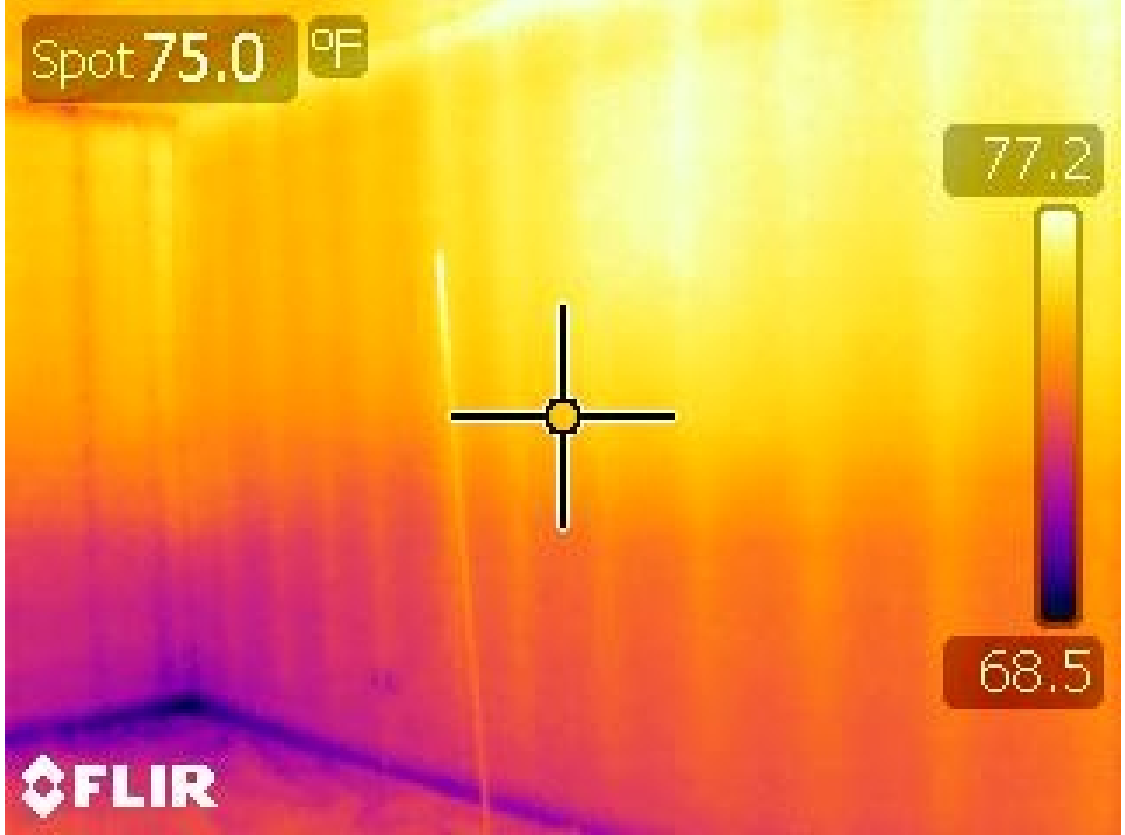

Figure 16. IR photo showing vertical stratification (temperature scale in ${ }^{\circ} \mathrm{F}$ )

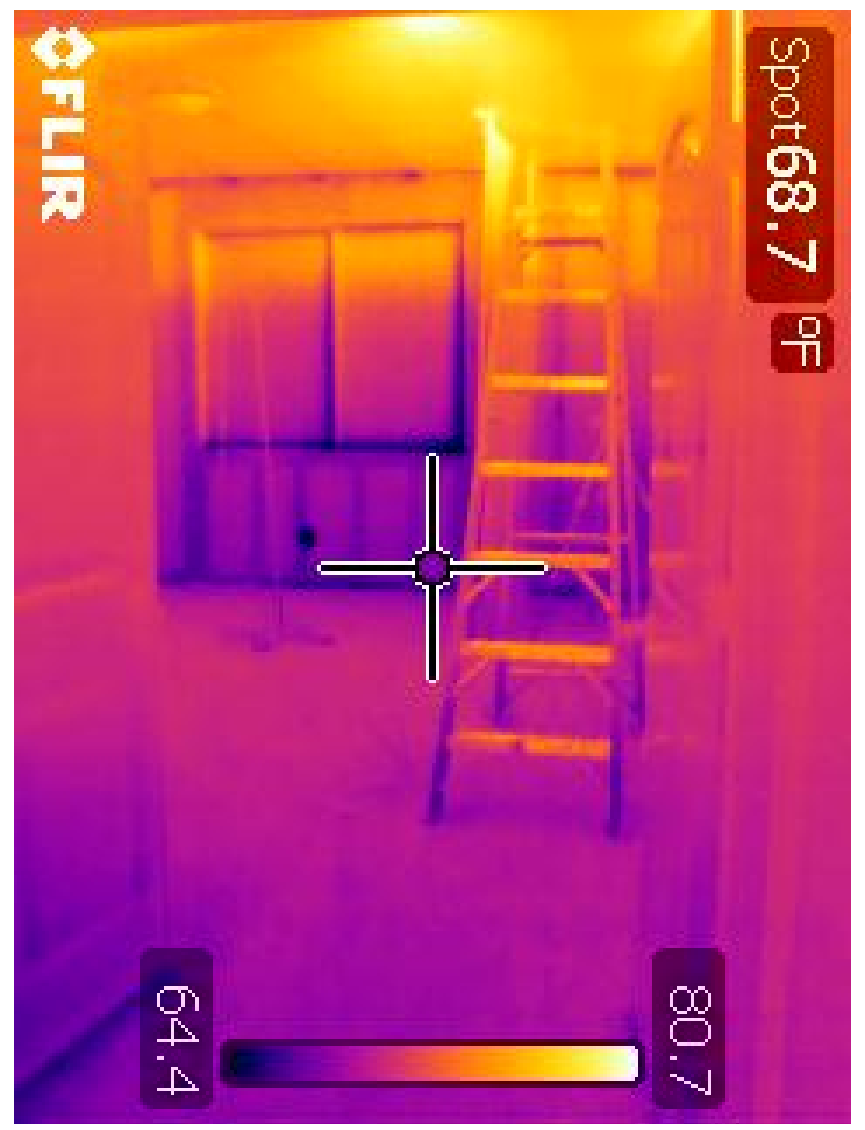

Figure 17. IR photo showing uniform horizontal distribution of heated air (temperature scale in ${ }^{\circ} \mathrm{F}$ ) 


\subsubsection{Discussion}

The use of modern IR equipment in an as-built house was able to confirm observations made by researchers 56 years ago. High supply temperatures from ceiling registers result in the separation of the warm and cool layers of air in the room and insufficient mixing. This is true regardless of the register placement, as verified by testing houses with the experimental register placement toward the interior of the room and the builder's standard placement toward the exterior wall.

Temperature stratification observed via IR photography during and after heating system operation indicated a difference of approximately $7^{\circ} \mathrm{F}\left(3.9^{\circ} \mathrm{C}\right)$ between the head and ankles of a standing occupant. According to ASHRAE Standard 55, this house would fall into Class C of Section 5.2.4.3 Vertical Temperature Difference, and approximately 15\% of the occupants would be dissatisfied (ASHRAE 2010b).

The results of this test would have been optically superior if a smaller fixed range had been used on the IR camera. Given the placement of the camera relative to the supply register and black felt assembly, an upper temperature of $90^{\circ} \mathrm{F}\left(32^{\circ} \mathrm{C}\right)$ may have been sufficient and would have provided superior contrast in the images. The use of autorange provides a sharper contrast but results in difficulty in comparison of images later.

\subsection{In-Room Temperature Uniformity Measurements \\ 3.7.1 Methods}

The performance of the ceiling-mounted supply registers located toward the interior of the house also was evaluated by taking temperature measurements at five critical locations throughout the master bedroom and six locations throughout the kitchen/family room area, including the supply air temperature and the room air near the window, near the opaque exterior wall, in the center of the room, and near an interior partition wall (see Figure 18). 


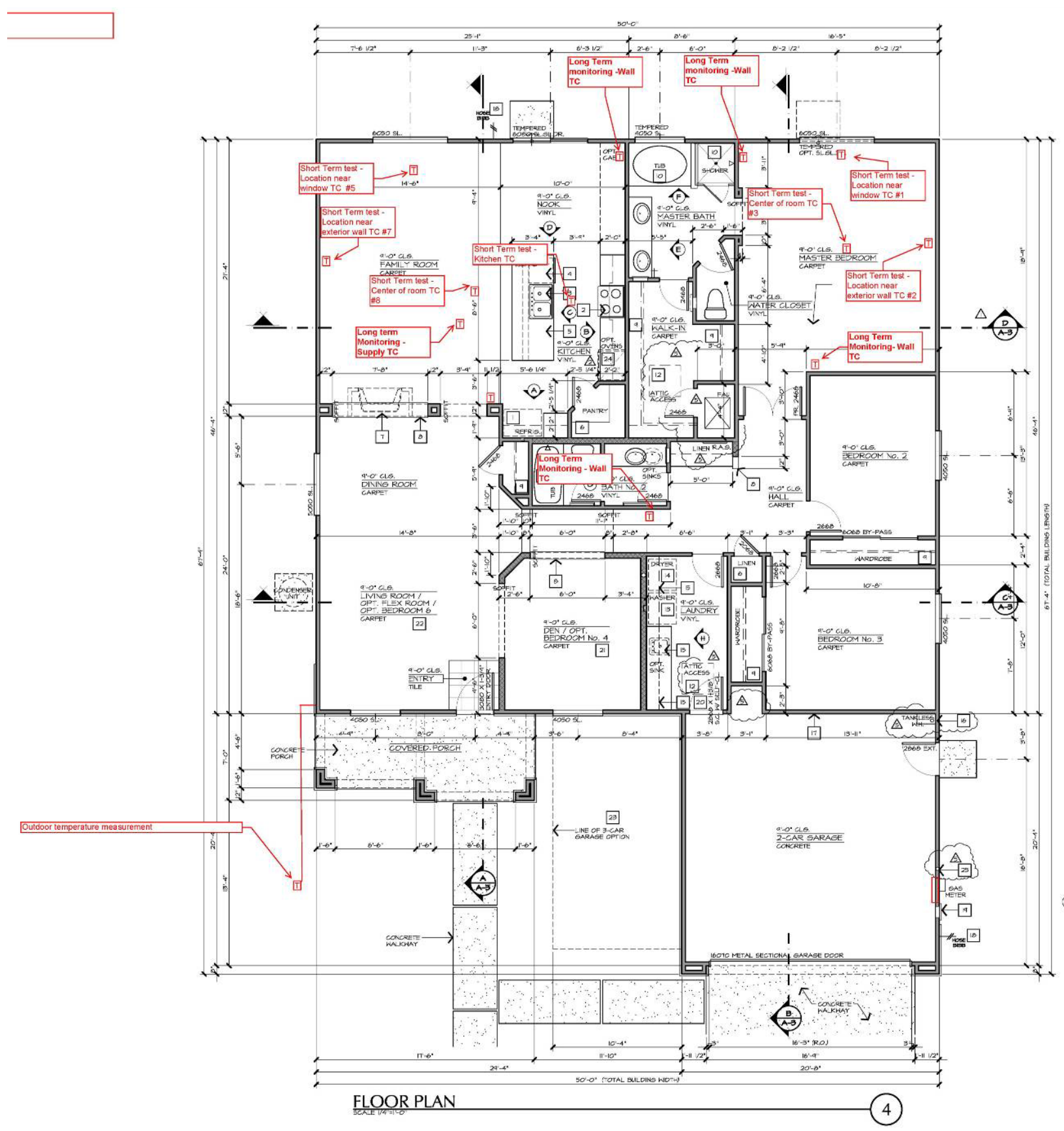

Figure 18. Layout of temperature measurements

Temperature was measured using thermocouples mounted 43 in. above the FF using test stands made of wooden dowel rods inserted into an " $x$ " base (see Figure 19). The temperature measurements consisted of thermocouple wire with ends twisted together (a junction) at the measurement point and the other end of the wire connected to a data logger, sampling every $20 \mathrm{~s}$ and averaging every minute and hour. Temperature measurements were conducted for an 11-h period over 1 night. Furnace and AHU runtime was not directly measured via electrical 
measurements during this time due to sensor malfunction. However, runtime was obtained indirectly using the temperature measured at the supply register, which increased dramatically during furnace operation.

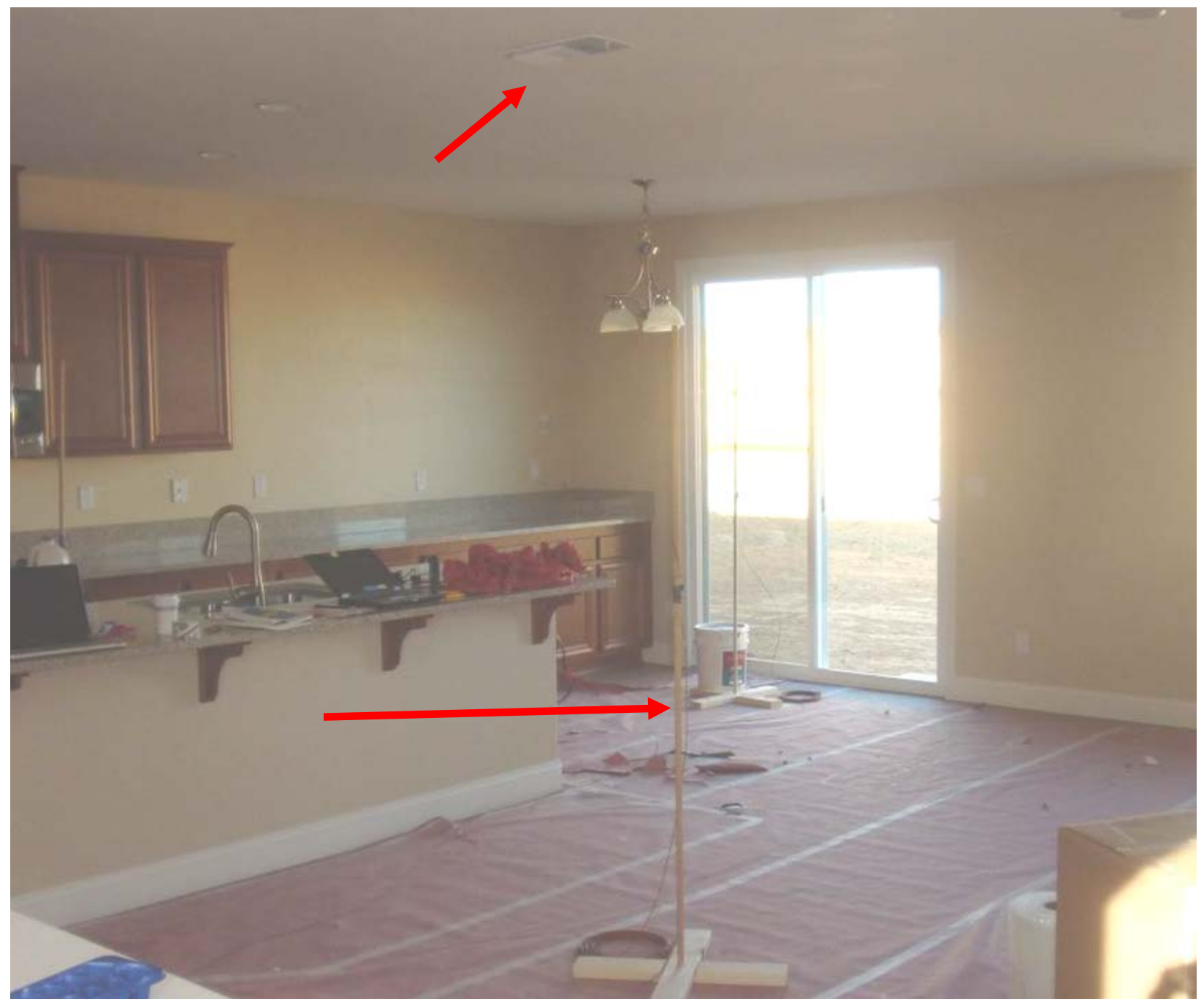

Figure 19. Sensor stands and a supply register in the kitchen/family room area

\subsubsection{Results}

During the 11 -h test, the outdoor temperature ranged from $48.0^{\circ}$ to $39.9^{\circ} \mathrm{F}$. The indoor temperature measured at the thermostat ranged from $71.6^{\circ}$ to $72.5^{\circ} \mathrm{F}$, and the furnace ran 39 times.

Results showed temperatures within $\pm 5.4^{\circ} \mathrm{F}$ throughout the kitchen/family room area and $\pm 1.8^{\circ} \mathrm{F}$ throughout the master bedroom. The only large variation in temperature was because two sensors in the kitchen/family room area were hit directly by the flow of heated air provided by the register. The most affected sensor (T_Nook_Avg) was part of the long-term monitoring equipment. Located at the same height as all other sensors (43 in. above FF) on an interior 
partition wall near the exterior wall and approximately $10 \mathrm{ft}$ horizontally from the register, its intended purpose was to measure the conditions near the exterior wall. Although it was unintentional that this sensor was hit by the register airflow, it is indicative of the ability of conditioned air to reach the exterior wall. Figure 20 shows an example of the variation observed in sensor locations in the kitchen/family room area during the course of a typical hour when three heating cycles occurred. The temperature measurements in the master bedroom did not display this behavior (see Figure 21) because their locations were not directly in line with the airstream from the heating supply register. Ignoring this behavior, intraroom variation in temperature in the kitchen/family room area was within $1.8^{\circ} \mathrm{F}\left(1.0^{\circ} \mathrm{C}\right)$.

The maximum temperature of air leaving the heating register was $118^{\circ} \mathrm{F}\left(48.0^{\circ} \mathrm{C}\right)$. Cyclical behavior observed in Figure 20 and Figure 21 was consistent throughout the 11-h test period.

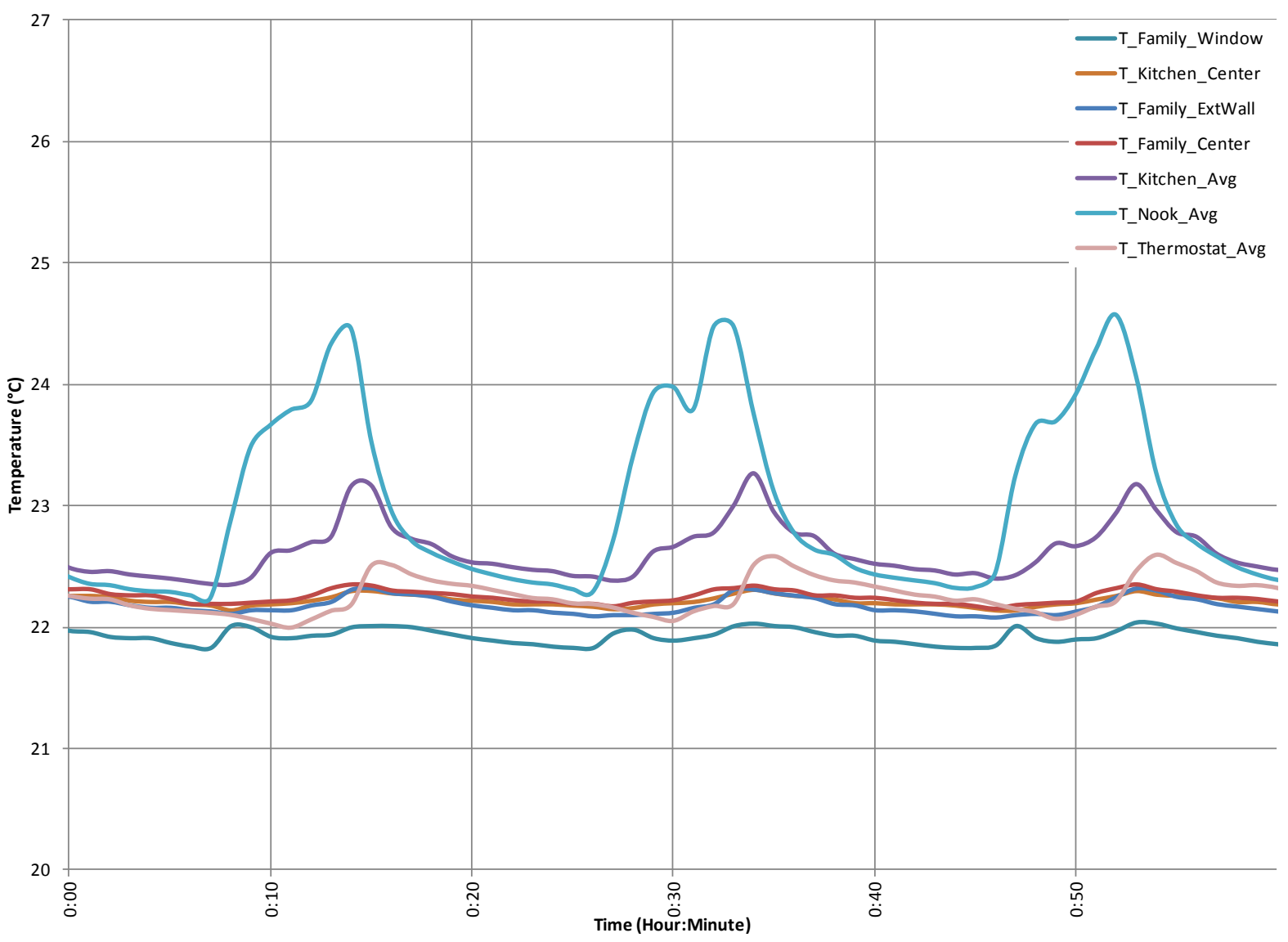

Figure 20. Temperatures $\left({ }^{\circ} \mathrm{C}\right)$ at various sensor locations in the kitchen/family room area during $1 \mathrm{~h}$ 


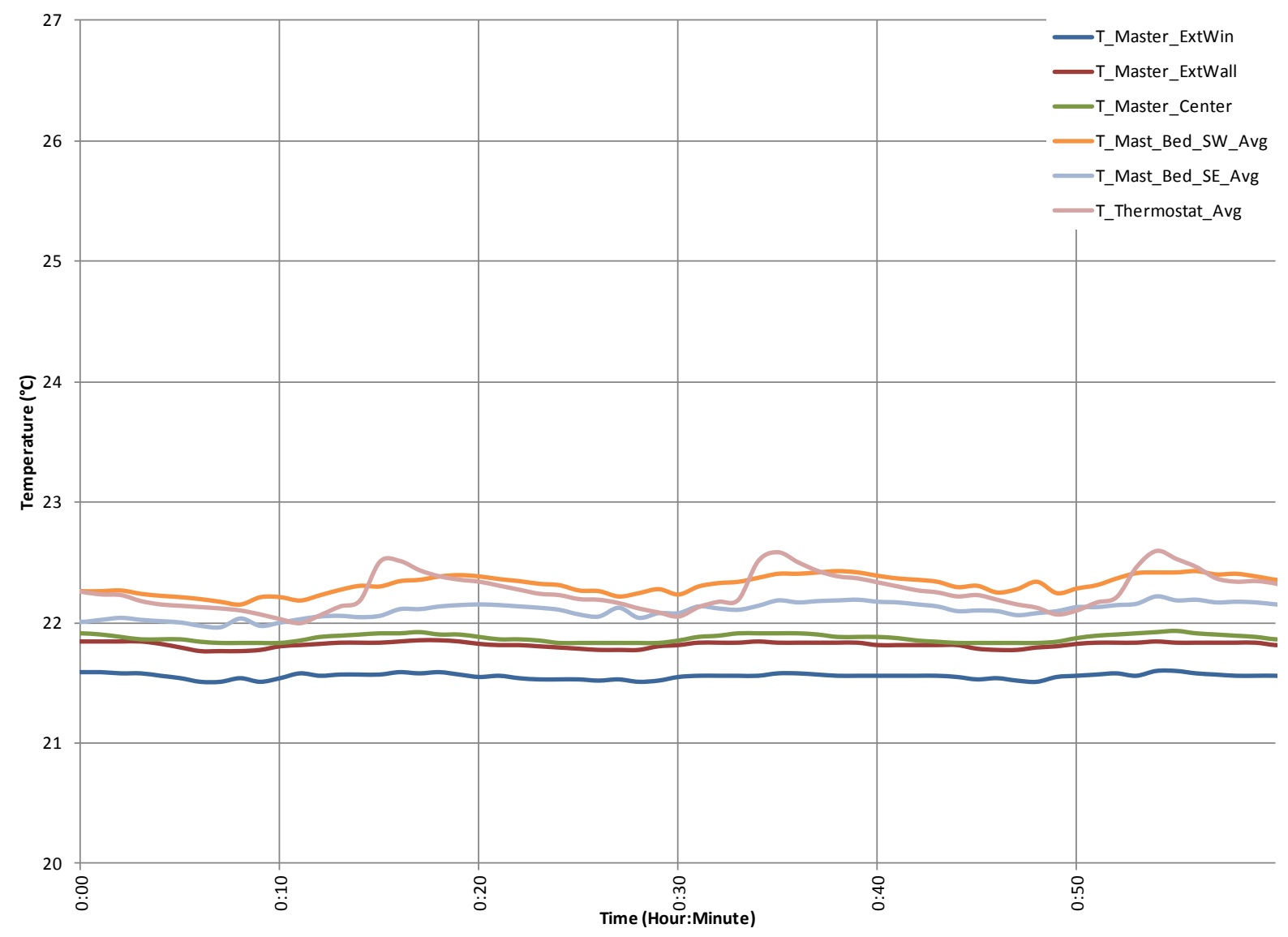

Figure 21. Temperatures $\left({ }^{\circ} \mathrm{C}\right)$ at various sensor locations in the master bedroom during $1 \mathrm{~h}$

\subsubsection{Discussion}

The purpose of these measurements was to determine the ability of the distribution system to maintain uniform temperatures throughout the air space of two observed rooms. The results show that the measurements did this successfully. Although the room air temperature was uniform when the impact of the heating system operation was ignored, the reality is that occupants in those locations at those times of system operation would experience those disruptions. It is important to remember that, although the heating system is responsible for eliminating large trends in temperature difference over time, it does this by causing small but substantial disruptions in temperature at regular intervals. 


\section{Conclusions}

As a result of the builder, design consultant, and trades working collaboratively to identify a package of measures satisfying the requirements of the CEC 2008 Building Energy Efficiency Standards (CEC 2010) and to prepare for the proposed 2013 CEC code and ENERGY STAR Version 3.0 requirements, the test house constructed in Roseville, California, has a modeled energy savings of $60 \%$ with respect to the BA House Simulation Protocols (Hendron and Engebrecht 2010). The energy improvements were implemented without requiring changes to the drawings that would have impacted local code or zoning approval.

Short-term testing results showed that duct air leakage was low, as anticipated, due to the short duct runs and the placement of the ductwork in conditioned space. However, one problem foreseen during planning was realized during commissioning, where the lack of access for servicing the ductwork and dampers in the bulkhead area prevented retroactive balancing of individual branches, resulting in significant differences between specified and measured airflow values for some duct runs. The results of thermal imaging performed for the house when operating in heating and cooling modes showed that the alternative register placement in the test house provided equivalent horizontal distribution to the builder's standard house. The tests validated historical stratification issues of ceiling supply registers with high supply air temperatures.

Research questions will continue to be addressed through the data gathered by the long-term monitoring equipment and will be reported at the end of the testing period. 


\section{References}

ACCA (2010). ANSI/ACCA Standard 5 QI-2010: HVAC Quality Installation SpecificationResidential and Commercial Heating, Ventilating, and Air Conditioning (HVAC) Applications. Arlington, VA: ACCA.

ASHRAE (2010a). ANSI/ASHRAE Standard 62.2 - 2010, Ventilation and Acceptable Indoor Air Quality in Low-Rise Residential Buildings. Atlanta, GA: ASHRAE.

ASHRAE (2010b). ANSI/ASHRAE Standard 55-2010, Thermal Environmental Conditions for Human Occupancy. Atlanta, GA: ASHRAE.

California Building Standards Commission (2007). 2007 California Building Code, Title 24. Sacramento, CA: California Building Standards Commission.

CEC (2010). 2008 Building Energy Efficiency Standards: Residential Compliance Manual. Revised July 2010. Sacramento, CA: CEC.

Hendron, R.; Engebrecht, C. (2010). Building America House Simulation Protocols. NREL/TP550-49426. Golden, CO: National Renewable Energy Laboratory.

International Energy Conservation Code. (2009). International Energy Conservation Code. Washington, DC: International Code Council (ICC).

International Energy Conservation Code (2012). International Energy Conservation Code. Washington, DC: ICC.

Rutkowski, H. (1997). Manual RS-Comfort, Air Quality, and Efficiency by Design. 1st ed. Washington, DC: Air Conditioning Contractors of America Educational Institute, pp. 1-9.

Straub, H.E. (1957). "Distribution of Air Within a Room for Year-Round Air Conditioning." Engineering Experiment Station Bulletin 442; pp. 19-28. Urbana, IL: University of Illinois. 

Renewable Energy 